Atmos. Chem. Phys., 17, 12379-12403, 2017

https://doi.org/10.5194/acp-17-12379-2017

(c) Author(s) 2017. This work is distributed under

the Creative Commons Attribution 3.0 License.

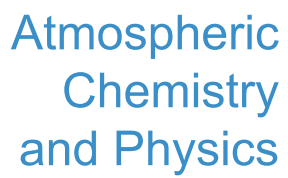

(c) (P)

\title{
Sources of sub-micrometre particles near a major international airport
}

\author{
Mauro Masiol $^{1,2}$, Roy M. Harrison ${ }^{1, a}$, Tuan V. Vu ${ }^{1}$, and David C. S. Beddows ${ }^{1}$ \\ ${ }^{1}$ Division of Environmental Health and Risk Management, School of Geography, Earth and Environmental Sciences, \\ University of Birmingham, Edgbaston, Birmingham, B15 2TT, UK \\ ${ }^{2}$ Division of Epidemiology, Department of Public Health Sciences, University of Rochester Medical Center, \\ 265 Crittenden Boulevard, CU 420644, Rochester, NY 14642, USA \\ aalso at: Department of Environmental Sciences/Center of Excellence in Environmental Studies, King Abdulaziz University, \\ P.O. Box 80203, Jeddah, 21589, Saudi Arabia
}

Correspondence to: Roy M. Harrison (r.m.harrison@bham.ac.uk)

Received: 16 February 2017 - Discussion started: 26 April 2017

Revised: 31 August 2017 - Accepted: 5 September 2017 - Published: 18 October 2017

\begin{abstract}
The international airport of Heathrow is a major source of nitrogen oxides, but its contribution to the levels of sub-micrometre particles is unknown and is the objective of this study. Two sampling campaigns were carried out during warm and cold seasons at a site close to the airfield $(1.2 \mathrm{~km})$. Size spectra were largely dominated by ultrafine particles: nucleation particles $(<30 \mathrm{~nm})$ were found to be $\sim 10$ times higher than those commonly measured in urban background environments of London. Five clusters and six factors were identified by applying $k$ means cluster analysis and positive matrix factorisation (PMF), respectively, to particle number size distributions; their interpretation was based on their modal structures, wind directionality, diurnal patterns, road and airport traffic volumes, and on the relationship with weather and other air pollutants. Airport emissions, fresh and aged road traffic, urban accumulation mode, and two secondary sources were then identified and apportioned. The fingerprint of Heathrow has a characteristic modal structure peaking at $<20 \mathrm{~nm}$ and accounts for $30-35 \%$ of total particles in both the seasons. Other main contributors are fresh (24-36\%) and aged (16-21\%) road traffic emissions and urban accumulation from London (around 10\%). Secondary sources accounted for less than $6 \%$ in number concentrations but for more than $50 \%$ in volume concentration. The analysis of a strong regional nucleation event showed that both the cluster categorisation and PMF contributions were affected during the first $6 \mathrm{~h}$ of the event. In 2016, the UK government provisionally approved the construction of
\end{abstract}

a third runway; therefore the direct and indirect impact of Heathrow on local air quality is expected to increase unless mitigation strategies are applied successfully.

\section{Introduction}

Emerging markets, developing economies and globalisation have driven a fast and continuing growth of civil aviation in the last decades (Lee et al., 2009); this trend is still growing by $\sim 5.5 \% \mathrm{y}^{-1}$ (ICAO, 2017). As a consequence, the aircraft and road traffic at airports is also increasing, but the information available on the impact of airport emissions upon air quality at ground level is still inadequate (Webb et al., 2008; Masiol and Harrison, 2014). The quantification of airport impacts on local air quality is complicated by the complexity of multiple mobile and static emission sources, with many airports being located near major cities, highways or industrial plants. Consequently, the development of successful strategies for emission mitigation and the implementation of measures for air quality improvement to meet regulatory standards require a detailed quantification of the contribution of airport and other emissions to the total air pollution load.

Biological evidence associates the exposure to ultrafine particles (UFPs, $<100 \mathrm{~nm}$ ) with adverse effects upon human health (e.g. Knibbs et al., 2011; Strak et al., 2012; Ostro et al., 2015; Lanzinger et al., 2016). At the current time, there is still limited knowledge of what specific characteris- 
tic or association of characteristics may dominate the particle toxicity and the consequent health outcomes (Atkinson et al., 2010; Strak et al., 2012; Vu et al., 2015a); nevertheless, it is well recognised that UFPs can reach the deepest regions of the lung (Salma et al., 2015) and may have orders of magnitude higher surface-area-to-mass ratios compared to larger particles. They offer more surface for the absorption of volatile and semi-volatile species (Kelly and Fussell, 2012; Strak et al., 2012).

Several studies have reported large increases in UFPs near airports (e.g. Westerdahl et al., 2008; Hu et al., 2009; Klapmeyer et al., 2012; Hsu et al., 2012a, b). For example, Hsu et al. (2013) and Stafoggia et al. (2016) detected substantial increases in total particle number concentration (PNC) at the airports of Los Angeles (CA, USA) and Rome Ciampino (Italy), respectively, in the few minutes after take-offs, especially downwind, while landings made only a modest contribution to ground-level PNC observations. Hsu et al. (2014) observed that departures and arrivals on a major runway of Green International Airport (Warwick, RI, USA) had a significant influence on UFP concentrations in a neighbourhood proximate to the end of the runway. In a study carried out at Los Angeles International Airport (CA, USA), Hudda et al. (2014) concluded that emissions from the airport increase PNC by 4 - to 5 -fold at $8-10 \mathrm{~km}$ downwind of the airfield, while Shirmohammadi et al. (2017) reported that the daily contributions of the airport to PNC were approximately 11 times greater than those from three surrounding freeways. Hudda et al. (2016) reported that average PNC were 2- and 1.33 -fold higher at sites 4 and $7.3 \mathrm{~km}$ from Boston (MA, USA) airport when winds were from the direction of the airfield compared to other directions.

Despite the strong evidence that airports are major sources of UFPs, their fingerprint within the particle number size distribution (PNSD) may be difficult to identify due to (i) the nature of semi-volatile compounds emitted by aircraft, (ii) the possible mechanisms of secondary aerosol formation, (iii) the dilution effect and (iv) the similar modal structures of other emission sources concurrently found in cities, such as road traffic (Masiol and Harrison, 2014). Generally, studies performed within or close to airports have reported increases in particles ranging from 4 to $100 \mathrm{~nm}$ in diameter and mostly distributed in the nucleation range $(<30 \mathrm{~nm})$. For example, Mazaheri et al. (2009) showed a main nucleation mode and an accumulation mode $(40-100 \mathrm{~nm})$ more evident during take-offs; Keuken et al. (2015) reported PNSD dominated by $10-20 \mathrm{~nm}$ particles in an area affected by emissions from Schiphol airport (the Netherlands); Hudda and Fruin (2016) found strong increases in particles smaller than $40 \mathrm{~nm}$ downwind of Los Angeles International Airport; Ren et al. (2016) showed that particles peaking at $16 \mathrm{~nm}$ dominate the PNSD at various distances from the runway of Tianjin International Airport, China; Masiol et al. (2016) reported that the fingerprint of aircraft emissions sampled under real ambient conditions at the airport of Venice (Italy) has a main mode at approx. $80 \mathrm{~nm}$ and a second mode in the nucleation range below $14 \mathrm{~nm}$.

The Greater London area is home to more than 8.5 million inhabitants and is one of the few UK locations not fully achieving the EU and national air quality standards: in 2015 nitrogen dioxide breached the hourly and annual limit values for health, while ozone exceeded the long-term objective (DEFRA, 2016). However, the standards were fully met for both $\mathrm{PM}_{10}$ and $\mathrm{PM}_{2.5}$.

London Heathrow (LHR) is one of the world's busiest international airports: it is ranked first in Europe for total passenger traffic (ACI, 2016). It accommodates more than 1250 flights every day and serves a total of 72.3 million passengers $\mathrm{y}^{-1}$. LHR is composed of five terminals and two runways: northern (3.9 km long) and southern ( $3.7 \mathrm{~km}$ long). Currently, runways operate near their maximum capacity, with a consequent increase in the potential for delays when flights are disrupted. Since 2007, the proposal for expanding LHR with a third runway and a sixth terminal has been intensely debated in the UK. In 2016 the UK government provisionally approved the construction of a third runway (UK Department for Transport, 2017).

LHR is located west of London (Fig. SI1 in the Supplement). Consequently, air quality in the surroundings of the airport may be affected by the advection of air masses from the city, with the associated high levels of pollutants emitted from traffic, energy demand for domestic heating and local industries. Airport activities may also contribute to air pollution advected to the city when LHR is upwind, with consequent potential impacts upon public health. In addition, as LHR attracts a large number of passengers and workers, the emissions from large volumes of road traffic generated by the airport and the nearby M4 and M25 motorways are difficult to discriminate from non-airport-related road traffic. Due to this complex scenario, the contribution of LHR is difficult to differentiate from the urban background pollution, as already reported by previous modelling and experimental studies (Farias and ApSimon, 2006; Masiol and Harrison, 2015).

Various studies have attempted to quantify the effect of LHR upon air quality, mainly focusing on the nitrogen oxides $\left(\mathrm{NO}_{x}=\mathrm{NO}+\mathrm{NO}_{2}\right)$, which are well-known tracers for aircraft engine exhausts (e.g. Herndon et al., 2008; Masiol and Harrison, 2014 and references therein) but also arise from other combustion sources. For example, Carslaw et al. (2006) estimated that airport operations in 2001/4 accounted for $\sim 27 \%$ of the annual mean $\mathrm{NO}_{x}$ and $\mathrm{NO}_{2}$ at the airfield boundary and less than $15 \%\left(<10 \mu \mathrm{g} \mathrm{m}^{-3}\right)$ at background locations $2-3 \mathrm{~km}$ downwind of the airport. Similar results were found for the 2008/9 period using model evaluation (AEA, 2010) and for the 2005/12 period using experimental data analysis (Masiol and Harrison, 2015). This latter study also reported that particulate matter (PM) mass concentrations at eight sites all around LHR were always well below the EU and UK limit. 
This study aims to investigate the impacts of a major airport (LHR) serving a megacity (London) upon the levels of sub-micrometre particles and to apportion those impacts to aircraft, road traffic and other sources typical of large cities with airports. The main particle size distributions modes are simplified by applying cluster analysis; then, the modal structures of the main potential sources are disaggregated and the submicron particle number concentrations (PNC) are quantified through the positive matrix factorisation (PMF). In addition, the origin of the airport plumes was spatially assessed by matching results with local meteorological data, air mass movements, levels of common air pollutants, $\mathrm{PM}_{2.5}$ mass concentration and its chemical speciation as indicators of source location and formation mechanisms.

The atmospheric chemistry and physical properties of UFPs have been extensively investigated in London (e.g. Harrison et al., 2012; Jones et al., 2012; von Bismarck-Osten et al., 2013) with several studies using cluster analysis (Beddows et al., 2009; Brines et al., 2014, 2015) or PMF (Beddows et al., 2015; Vu et al., 2016). However, this study is the first one carried out in south-west London to characterise and quantitatively apportion the impacts of LHR under real ambient conditions. Moreover, only one earlier study (Masiol et al., 2016) has used both cluster analysis and PMF to directly assess the airport contributions to UFPs. In addition, this study also investigated the effects of a regional nucleation event on the results of the two source apportionment methods.

\section{Materials and methods}

\subsection{Experimental}

Two sampling campaigns (each 1 month long) were carried out during warm (August-September 2014) and cold (December 2014-January 2015) periods at Harlington (Fig. SI1). The site was selected as well located to sample the plumes from the airport emissions: it lies $1.2 \mathrm{~km}$ north of the northern runway and is located inside a playground, close to a secondary road and near the village of Harlington. This is the location selected for the construction of the third runway. The site is categorised as "urban industrial" by the UK Department for Environment, Food and Rural Affairs (DEFRA; http://uk-air.defra.gov.uk/), and it is therefore more indicative of community exposure rather than direct fresh aircraft emissions. Consequently, it is a good point to quantify the particles generated by the airport after a relatively short ageing and dispersion in the atmosphere and is more indicative of the fingerprint of aircraft emissions affecting communities than data collected alongside the runway or in the airport apron areas. In addition, previous studies have reported that the site is strongly affected by the plume from the airport (Carslaw et al., 2006; Masiol and Harrison, 2015). Prevailing winds from the third and fourth quadrants are recorded in both summer and winter (Fig. SI2): under such circulation regimes, Harlington lies just downwind of LHR. The site is also affected by pollutants arising from the large volumes of road traffic within London, from the local road network as well as those generated by the airport. Tunnel Rd, the main access to LHR from the M4 motorway lies $800 \mathrm{~m}$ west, as do the nearby M4 (640 m north) and M25 ( 3.5 km east) motorways and major roads (Bath Rd, part of A4, passes $900 \mathrm{~m}$ south; A30 lies $2.8 \mathrm{~km} \mathrm{SE})$. The village of Harlington ( $\sim 400 \mathrm{~m}$ west) and advection of air masses from the conurbation of London are other potential external sources.

Ultrafine particle counts and their size distributions from 14.3 to $673.2 \mathrm{~nm}$ were measured at $5 \mathrm{~min}$ time resolution using an SMPS (scanning mobility particle sizer) spectrometer comprising an electrostatic classifier TSI 3080 with a long differential mobility analyser (TSI 3081) and a CPC (condensation particle counter; TSI 3775) based on condensation of $n$-butyl alcohol (Fisher Scientific, ACS). The SMPS operated at a sheath-air-to-aerosol flow ratio of $10: 1$ (sheath and sample air flow rates were 3.0 and $0.3 \mathrm{~L} \mathrm{~min}^{-1}$, respectively; voltage, $10-9591 \mathrm{~V}$; density, $1.2 \mathrm{~g} \mathrm{~cm}^{-3}$; scan time, $120 \mathrm{~s}$; retrace, $15 \mathrm{~s}$; number of scans, 2) while the CPC operated at low flow rate $\left(0.3 \mathrm{~L} \mathrm{~min}^{-1}\right)$. The use of $5 \mathrm{~min}$ resolved spectra has already been used successfully for source apportionment purposes at an airport (Masiol et al., 2016).

Equivalent black carbon (eBC) as defined by Petzold et al. (2013) was also measured at 5 min resolution using a seven-wavelength aethalometer (Magee Scientific AE31). The aethalometer operated with an inlet cut-off head to collect $\mathrm{PM}$ with an aerodynamic diameter of $<2.5 \mu \mathrm{m}\left(\mathrm{PM}_{2.5}\right)$. eBC was derived from the absorbance at $880 \mathrm{~nm}$ wavelength (Petzold et al., 2013); raw data were post-processed with the Washington University Air Quality Lab AethDataMasher V7.1 to perform data validation and correct data for nonlinear loading effects (Virkkula et al., 2007; Turner et al., 2007).

Instruments were installed into a plastic or metal case designed for sampling purposes: (i) air inlets were $\sim 1.8 \mathrm{~m}$ above the ground and were composed of conductive materials to avoid particle losses and sampling artefacts; (ii) the case was cooled by fans in summer and was warmed by an electrical tubular heater in winter for maintaining an indoor air temperature within an acceptable range for running the equipment (temperature inside the case was recorded and periodically checked); (iii) instruments were isolated from vibration using rubber pads and foam foils. Devices were fully serviced, calibrated by authorised companies and underwent internal cross-calibrations with other similar instruments under lab conditions. Moreover, frequent periodic checks, maintenance of instruments and cleaning of inlets was performed throughout the sampling campaign.

Routine air pollutants (NO, $\mathrm{NO}_{2}, \mathrm{NO}_{x}, \mathrm{O}_{3}, \mathrm{PM}_{10}, \mathrm{PM}_{2.5}$ ) were measured at Harlington with $1 \mathrm{~h}$ time resolution by the UK Automatic Urban and Rural Network under the auspices of DEFRA. Gaseous species were analysed using au- 
tomatic instruments according to European standards and national protocols: EN 14211:2012 for nitrogen oxides and EN 14625:2012 for ozone. $\mathrm{PM}_{10}$ and $\mathrm{PM}_{2.5}$ were analysed using a tapered-element oscillating-microbalance and filter dynamics measurement system (TEOM-FDMS) to provide measurements accounting for volatile $\left(\mathrm{VPM}_{10}, \mathrm{VPM}_{2.5}\right)$ and non-volatile $\left(\mathrm{NVPM}_{10}, \mathrm{NVPM}_{2.5}\right)$ fractions. Quality assurance and quality control procedures followed the standards applied for the Automatic Urban and Rural Network (AURN) and the London Air Quality Network (LAQN). Instruments were routinely calibrated and were fully serviced and underwent intercalibration audits every 6 months.

Some additional variables are also computed from the air pollutants to help the interpretation of results. The $\mathrm{NO}_{2} / \mathrm{NO}_{x}$ ratio is indicative of the partitioning of nitrogen oxides, while the levels of oxidants ( $\mathrm{OX}=\mathrm{O}_{3}+\mathrm{NO}_{2}$, expressed in ppbv) can be used to roughly assess the oxidative potential in the atmosphere (Kley et al., 1999; Clapp and Jenkin, 2001). These two new variables are useful in investigating the atmospheric chemistry behind the $\mathrm{NO}-\mathrm{NO}_{2}-\mathrm{O}_{3}$ system. Delta-C (the difference between absorbance at 378 and $880 \mathrm{~nm}$, also called UVPM) was also computed. This variable was largely used as a proxy to estimate the fraction of carbonaceous material emitted by biomass burning (e.g. Sandradewi et al., 2008; Wang et al., 2011). However, Delta-C results should be used with caution: Harrison et al. (2013) showed that there are probably other UV-absorbing contributors than wood smoke to the aethalometer signal. Consequently, Delta-C is used here only for qualitative purposes.

Weather data were measured hourly by the Met Office at LHR; met data include wind direction and speed, atmospheric pressure, air temperature, relative humidity (RH), visibility, rain, and solar irradiance.

During the two campaigns, $24 \mathrm{~h} \mathrm{PM}_{2.5}$ samples were also collected on quartz filters using a high-volume air sampler (TE-6070, Tisch Environmental, Inc.) and analysed for the daily concentrations of major $\mathrm{PM}_{2.5}$ components: organic carbon (OC) and elemental carbon (EC) by thermo-optical analysis (EUSAAR_2 protocol) and major inorganic ions $\left(\mathrm{Na}^{+}, \mathrm{K}^{+}\right.$, ammonium, nitrate, sulfate, oxalate) by ion chromatography. Analytical methods are reported in detail in Yin et al. (2010). The results of the chemical speciation of $\mathrm{PM}_{2.5}$ are presented in a companion paper (in preparation) and are used in this study only to assist the interpretation of PMF results.

\subsection{Data handling and chemometric approaches}

Data were analysed using $\mathrm{R}$ version 3.3.1 (R Core Team, 2015) and a series of supplementary packages, including "Openair" (Carslaw and Ropkins, 2012). Preliminary data handling and clean-up were carried out to check the robustness of the dataset, detect anomalous records and to delete extreme outliers. SMPS data with unreliable behaviour or instrument errors were completely deleted. An in-depth anal- ysis of the dataset revealed a few records with anomalously high PNC, which were likely related to probable instrumental issues, extreme weather conditions (e.g. high wind gusts, heavy rain striking the inlet) or infrequent local emissions, e.g. maintenance, painting and recreational activities (including fires) on the playground where the site is located, road maintenance close the site, and probable short-term parking of high-emission vehicles near the site. Since this study aims to investigate the overall contributions of LHR, all data are used for descriptive statistics, but data greater than the 99.5th percentile were further removed for explorative, cluster and PMF analyses. This data exclusion successfully removed the extremely high events occurring during the sampling campaigns and significantly improved the stability and physical meaning of PMF solutions. Missing data for other variables were linearly interpolated between the nearest values of the time series.

The PNSDs were firstly grouped by applying a $k$ means cluster analysis. The full method is exhaustively discussed in Beddows et al. $(2009,2014)$ and aims to assemble single spectra into $k$ clusters. The clustering groups observations with spectra similar to their cluster centroids (means), i.e. observations that are likely generated by the same set of formation processes or emission sources. The optimum number of clusters $(k)$ was determined by an optimisation algorithm based on the spectral shapes (Beddows et al., 2009). The choice to apply the $k$ mean clustering method was based on several reasons: (i) Salimi et al. (2014) reported that $k$ means is the best-performing clustering among other methods tested on PNSD data; (ii) $k$ means is a well-established method which has been widely applied over a number of different sites (e.g. Dall'Osto et al., 2012; Wegner et al., 2012; Beddows et al., 2014; Brines et al., 2014, 2015); and (iii) the method was previously applied successfully to airport data (Masiol et al., 2016).

PMF analysis was performed by applying the U.S. EPA PMF5 model. Details of the PMF model are reported elsewhere (Paatero and Tapper, 1994; Paatero, 1997; U.S. EPA, 2014), while the best practice and standards are extensively reviewed in several papers (e.g. Reff et al., 2007; Belis et al., 2014; Brown et al., 2015; Hopke, 2016). SMPS data at $5 \mathrm{~min}$ resolution were used as the PMF input matrix. Uncertainties associated with SMPS data were estimated according to the empirical method proposed by Ogulei et al. (2007). Uncertainty for the total variable (total particle number concentration; PNC) was set to $300 \%$ of the PNC concentration and also marked as "weak" to avoid it driving the profiles.

The best PMF solutions were identified: (i) by investigating solutions between 3 and 10 factors, (ii) by considering the minimisation of the objective function $Q$ with respect to the expected (theoretical) value and its stability over multiple ( $n=100)$ runs, (iii) by obtaining low values for the sum of the squares of the differences in scaled residuals for each base run pair by species, (iv) by minimising the number of absolute scaled residuals over \pm 3 and by keeping them sym- 
metrically distributed, (v) by keeping the result uncertainties calculated by bootstrap (BS, $n=200$ ) and displacement (DISP) methods within an acceptable range (Paatero et al., 2014), (vi) by obtaining modelled total variable (PNC) successfully predicted $\left(R^{2}>0.9\right.$ and slopes $\left.\approx 1\right)$, and (vii) by avoiding the presence of edges in the G-space plots (Paatero et al., 2002) and, then, the presence of hidden/unresolved sources.

A series of additional tools were used to analyse the raw data, link source apportionment results to other variables, such as local atmospheric circulation and regional/transboundary transport of air masses. Briefly, polar plots aim to map pollutant average concentrations by wind speed and direction as continuous surfaces (Carslaw et al., 2006), while polar annuli plot by wind direction and hours of the day. The potential locations of distant sources were assessed using back-trajectory analysis and a concentration-weighted trajectory (CWT) model (Stohl, 1998). Back-trajectories were computed with the HYSPLIT4 model (Stein et al., 2015; Rolph, 2016) using NCEP/NCAR reanalysis gridded meteorological data. The set-up is as follows: $-96 \mathrm{~h}$ with a starting height of $500 \mathrm{ma.g} .1$. CWT is a method of weighting trajectories with associated concentrations to detect the most probable source areas of long-range transports of pollutants; it has been used and reviewed in a number of prior studies (e.g. Stohl, 1996; Lupu and Maenhaut, 2002; Squizzato and Masiol, 2015).

\section{Results and discussion}

\subsection{Overview of data}

The wind roses during the two sampling periods are provided in Fig. SI2. Descriptive statistics of all collected variables are reported as boxplots in Fig. SI3. PNSDs were initially split into three ranges: nucleation $(14-30 \mathrm{~nm})$, Aitken nuclei $(30-100 \mathrm{~nm})$ and accumulation $(>100 \mathrm{~nm})$. On average the total PNC during the warm season was $1.9 \times$ $10^{4}$ particles $\mathrm{cm}^{-3}$, of which $1.1 \times 10^{4}, 6.4 \times 10^{3}$ and $1.5 \times$ $10^{3}$ particles $\mathrm{cm}^{-3}$ were classified as nucleation, Aitken and accumulation ranges, respectively (Fig. SI3). During the cold season, the total average PNC was $2.2 \times 10^{4}$ particles $\mathrm{cm}^{-3}$, composed of $1.4 \times 10^{4}, 6.3 \times 10^{3}$ and $1.4 \times 10^{3}$ particles $\mathrm{cm}^{-3}$ as nucleation, Aitken and accumulation ranges, respectively (Fig. SI3). Concentrations lie between those of London, Marylebone Road (kerbside), and London, North Kensington (background), and nucleation particles were $\sim 10$ times higher than the annual average measured in North Kensington as reported by $\mathrm{Vu}$ et al. (2016), while Aitken particles were 1.9 times higher. It is therefore evident that the main difference lies in the concentration of the finest size ranges: in both seasons, spectra were dominated by UFP $\left(D_{\mathrm{p}}<100 \mathrm{~nm}\right)$ particles ( $\sim 92 \%$ of total PNC), which only accounted for $\sim 12 \%$ of total particle volume concentration
(PVC, computed by approximation to spherical particles). On the other hand, accumulation-mode particles accounted for $\sim 8 \%$ of PNC and $~ 88 \%$ of PVC volume. The high levels of total PNC are not surprising: several studies carried out into or close to airports (e.g. Hsu et al., 2013, 2014; Hudda et al., 2014, 2016; Stafoggia et al., 2016; Shirmohammadi et al., 2017) reported significant increases in the concentrations of UFPs.

During the two sampling campaigns, air pollutants measured in Harlington (Fig. SI3) were similar to the average concentrations measured over an 8-year period (2005-2012) in the vicinity of LHR (Masiol and Harrison, 2015). Consequently, despite the two short campaigns carried out in this study, results may be considered representative of the average levels of air pollution recorded at Harlington. The average concentrations of eBC were 2.4 and $2.1 \mu^{-3} \mathrm{~m}^{-3}$ during the warm and cold season, respectively. The average concentration of Delta-C was $0.1 \mu \mathrm{g} \mathrm{m}^{-3}$ during the warm season and $0.36 \mu \mathrm{g} \mathrm{m}^{-3}$ in winter.

Analysis of the data showed a non-normal distribution for most of the variables: the nonparametric Kruskal-Wallis oneway analysis of variance was therefore used to test the difference in concentrations over the two periods (Kruskal and Wallis, 1952): almost all variables are different at the 0.05 significance level, except for $\mathrm{NO}, \mathrm{NO}_{x}$ and $\mathrm{O}_{3}$. This result indicates a seasonal effect upon air quality in the LHR area and suggests investigating the sources over the two periods separately.

The average PNSDs are shown in Fig. 1 as well as their median distributions and interquartile ranges. Spectra are categorised by time of day (07:00-19:00 and 19:00-07:00 local time). In addition, the particle volume size distributions (PVSDs) are also provided. Results for the warm season show that the average daytime PNSD is dominated by a main peak in the nucleation range (extending below $14 \mathrm{~nm}$ ) and a second mode in the Aitken range (between 30 and $50 \mathrm{~nm}$ ). The nocturnal spectrum is characterised by a drop in the nucleation mode to concentration values similar to the Aitken peak (mode around $35 \mathrm{~nm}$ ). During the cold season, the average diurnal and nocturnal PNSDs present a main peak at 15$25 \mathrm{~nm}$ and a second mode at $70-100 \mathrm{~nm}$. In summary, both seasons show reductions in the finest modes during nighttime, while the second mode is almost constant throughout the day. As a consequence, the modal structure of PVSDs is also almost constant throughout the day.

The diurnal cycles of the third particle ranges, eBC, solar irradiation and airport movements are shown in Fig. 2. A comprehensive overview of the patterns for all the variables is provided in Fig. SI4. Generally, diurnal cycles derive from the interplay of emissions, dispersion and atmospheric chemical processes. Consequently, they need to be investigated along with patterns for airport and motorway traffic (Figs. 2 and SI5, respectively) and as polar annuli (Figs. SI6 and SI7) and polar plots (Figs. SI8 and SI9), which give preliminary insights into the origin and spatial location of 


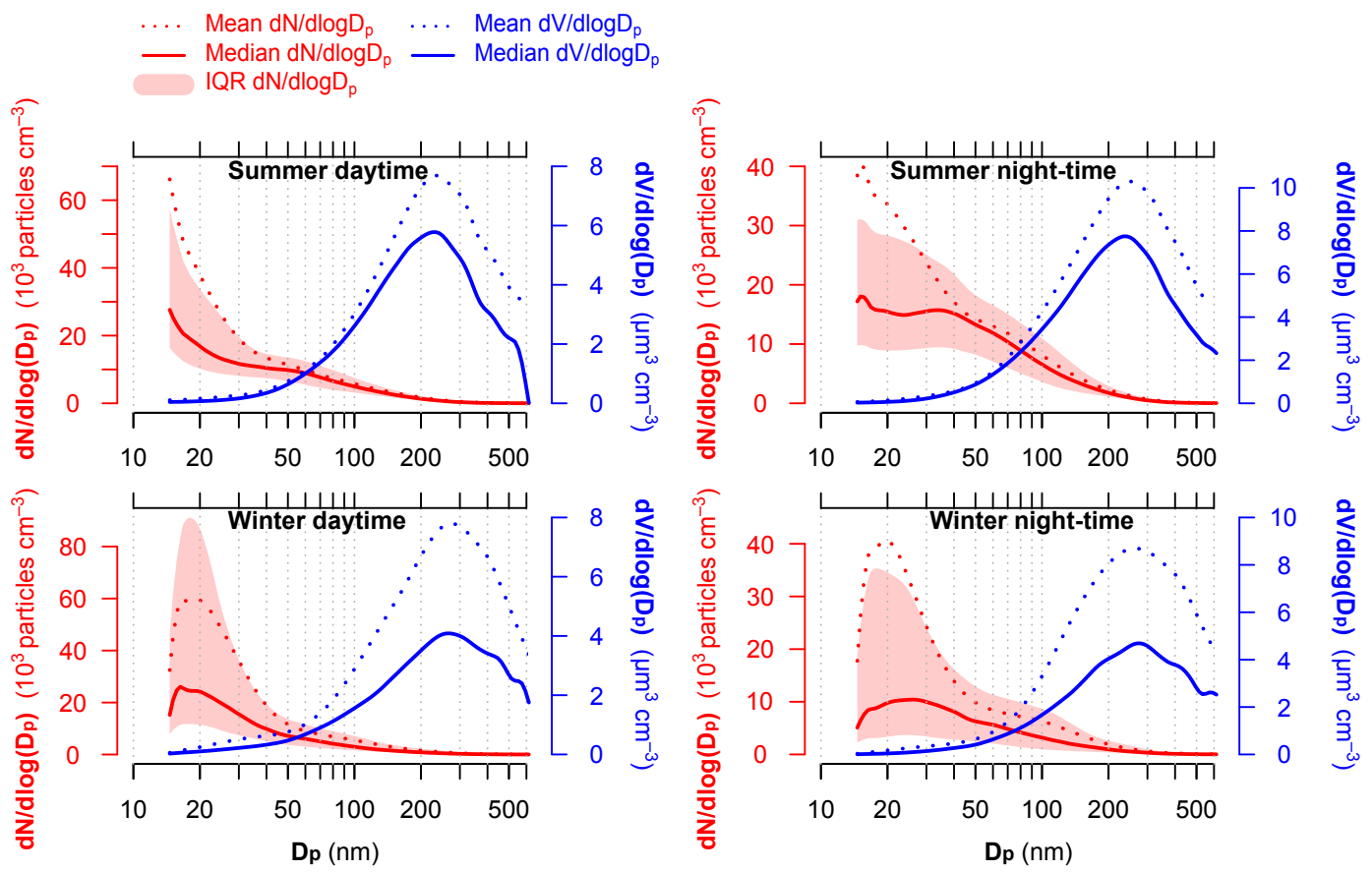

Figure 1. Statistics of size distribution spectra for particle number (red) and volume (blue) concentrations categorised by sampling periods and time of the day (daytime: 07:00-19:00; night-time: 19:00-07:00 local time). For the particle number spectra, solid lines represent the median concentrations, while shaded areas report the first to third quartile intervals (interquartile range, IQR). For the particle volume spectra, only medians are reported (dotted lines).
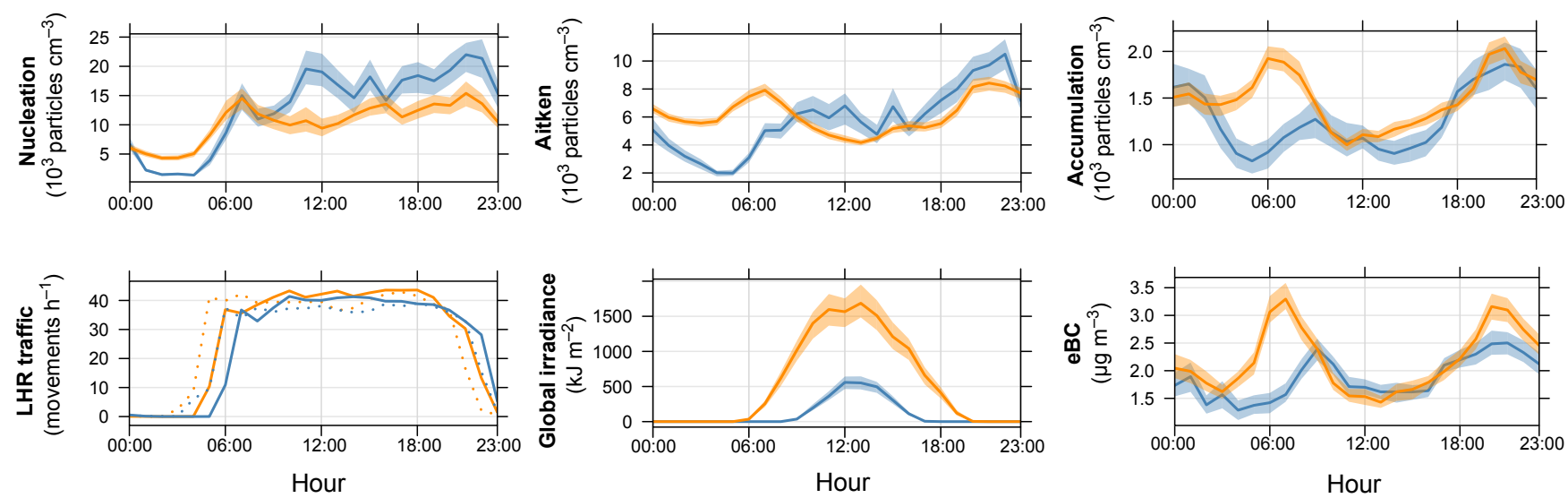

Figure 2. Diurnal patterns of PNC, LHR traffic, solar irradiance and eBC. Plots report the average levels as a filled line and the associated 95th confidence interval calculated by bootstrapping the data $(n=200)$. Outliers (data $>99.5$ th percentile) were removed for computing the diurnal patterns. Hours are given in UTC. LHR traffic movements (bottom right plot) are reported as arrivals (dotted lines) and departures (solid lines). The offset between the seasons is largely due to daylight saving time (BST: UTC +1$)$ in the summer data. The diurnal patterns of all the measured variables are reported in Fig. SI4.

the most probable emission sources. During night-time, airport traffic is restricted to limit noise and community disturbance: flights are generally constant from 06:00 to 20:00 and are kept at minimum overnight, with no departures normally scheduled between 23:00 and 06:00 (Fig. 2). Road traffic is more difficult to define. Data for the M4 and M25 motorways are provided by the UK Department for Transport: data for the M4 motorway show typical morning (07:00-08:00) and evening (17:00-18:00) peaks due to rush hours, but this pattern is not well-resolved for the M25 (Fig. SI5). In addition, despite it being likely that traffic on minor and local roads also follows patterns dominated by rush hours, traffic generated by the airport is more difficult to characterise, with Tun- 
nel $\mathrm{Rd}$ and other busy roads serving LHR being frequently congested.

Nucleation particles are likely associated with aircraft movements. The daily pattern shows high and almost constant concentrations between 07:00 and 23:00 (Fig. 2): hourly averages ranged from $10 \times 10^{3}$ to $15 \times$ $10^{3}$ particles $\mathrm{cm}^{-3}$ during the warm season and from $10 \times 10^{3}$ to $21 \times 10^{3}$ particles $\mathrm{cm}^{-3}$ during the cold season. By contrast, the concentrations of nucleation particles significantly (Kruskal-Wallis at $p<0.05$ ) drop overnight (hourly averages ranging from $5 \times 10^{3}$ to $6 \times 10^{3}$ particles $\mathrm{cm}^{-3}$ and from $1 \times 10^{3}$ to $5 \times 10^{3}$ particles $\mathrm{cm}^{-3}$ during the warm and cold season, respectively); the maximum average concentrations are recorded for winds blowing from the SW quadrant (polar plots and polar annuli in Figs. SI6-SI9), i.e. the airfield and, in particular, the location of the main LHR terminals (Fig. SI1). As a consequence of the dominance of nucleation particles over size spectra, total PNC also follows the pattern (Fig. 2) and wind directionality (Figs. SI8 and SI9) of nucleation particles. By contrast, accumulation particles appear to be more associated with road traffic. These particles increase for winds blowing from northern sectors (Figs. SI6SI9), i.e. toward the M4. Accumulation particles also present the morning (06:00-08:00) and evening (18:00-23:00) rush hour peaks during the warm season, but only the evening peak (from 18:00 to the night) was found in the cold season (Fig. 2). Generally, the evening peaks start around 18:00, which is consistent with the peak of traffic (Fig. SI5), but they extend late into the evening and night probably because of the drop in the mixing layer top and the consequent concentration of pollutants close to the ground level. Aitken nuclei exhibit a mixed behaviour between nucleation and accumulation particles (Fig. 2): two different patterns can be found, which are more consistent with road traffic in summer and with aircraft traffic in winter.

Despite some studies indicating that airports are strong sources of black carbon (Dodson et al., 2009), other studies report no strong relationships with the flight activity (Masiol et al., 2016). Similarly to $\mathrm{NO}_{2}$ (Fig. SI4) and accumulation particles (Fig. 2), aethalometer data also show typical patterns of road-traffic-influenced sites for all wavelengths, with two daily peaks corresponding to the hours with higher traffic (Fig. 2). However, Delta-C does not present any evident pattern (Fig. SI4). eBC shows increased concentrations when winds blow from northern sectors (plus SE in winter; Figs. SI7 and SI9); which excludes airport activities as being a dominant source in the study area.

Particulate matter mass concentration $\left(\mathrm{PM}_{10}\right.$ and $\left.\mathrm{PM}_{2.5}\right)$ has very weak diurnal patterns (Fig. SI4). Its wind directionality shows evident increases for northerly winds (Figs. SI8 and SI9). It is therefore evident that PM mass concentrations are dominated by non-airport sources, i.e. regional secondary pollutants, traffic from the nearby M4 or background pollution from London. $\mathrm{PM}_{2.5}$ concentrations normally do not ex- ceed the limit values in the Greater London area (DEFRA, 2016).

\section{2 $k$ means cluster analysis}

The clustering algorithm extracted five clusters for both periods. The number of clusters was selected according to the optimisation algorithm, i.e. local maxima in the Dunn indices and silhouette (Beddows et al., 2009). The extraction of five clusters represents a good compromise for the interpretation of spectral observations. Hussein et al. (2014) reported that is not prudent to describe the spectra with few clusters (2-4), which are not sufficient to explain variations and detailed differences in the PNSD observed in the urban atmosphere. On the other hand, they also reported that extracting too many ( $>10)$ clusters may make the aerosol source attribution more challenging.

The cluster centroids (mean spectra of each cluster), the 10th, 25th, 75th and 90th percentile, the hourly counts patterns, and resulting wind roses are shown in Figs. 3 and 4 for the warm and cold season campaigns, respectively. Despite extracted clusters exhibiting significantly different modal structures for PNC, no differences can be observed for the particle volume size spectra, which all show a unimodal peak at approx. 200-300 nm. Clusters accounted for 14-25\% of total observations for both the seasons: Table SI1 summarises the percentage of the total observations for each cluster.

Three clusters (cluster 1 during the warm season and clusters 1 and 5 in winter) are likely shaped by the airport emissions. The modal structures present sharp peaks for nucleation particles which extend below the SMPS detection limit (14 nm) and drop at 30-40 nm; no secondary modes are present in the Aitken or accumulation ranges. These clusters show a large increase in frequency during the afternoon and evening hours (cluster 1 for the warm season and cluster 5 for the cold season) or extend over the daytime (cluster 1 for the cold season), similarly to the airport aircraft movement profiles (Fig. 2). Aircraft are known to emit particles in the nucleation range (e.g. Mazaheri et al., 2009, 2013; Masiol and Harrison, 2014; and references therein; Lobo et al., 2015), and the wind roses are also compatible with an origin in the airfield and the main LHR terminals (Figs. 3 and 4). However, daytime regional photochemical nucleation events in London occur around 12:00-14:00 and are mostly recorded from June to September (Vu et al., 2016). Consequently, the modal structure of cluster 1 for the warm season could be additionally shaped by regional photochemical nucleation. The reasons driving the split of the spectra likely shaped by LHR into two clusters during the cold season are unclear. A further comparison of the cluster and PMF results will help in interpreting this outcome.

The modal structures of cluster 4 for both seasons peak for nucleation particles and extend below $14 \mathrm{~nm}$, but also show probable modes between 50 and $200 \mathrm{~nm}$ (Figs. 3 and 4). They 

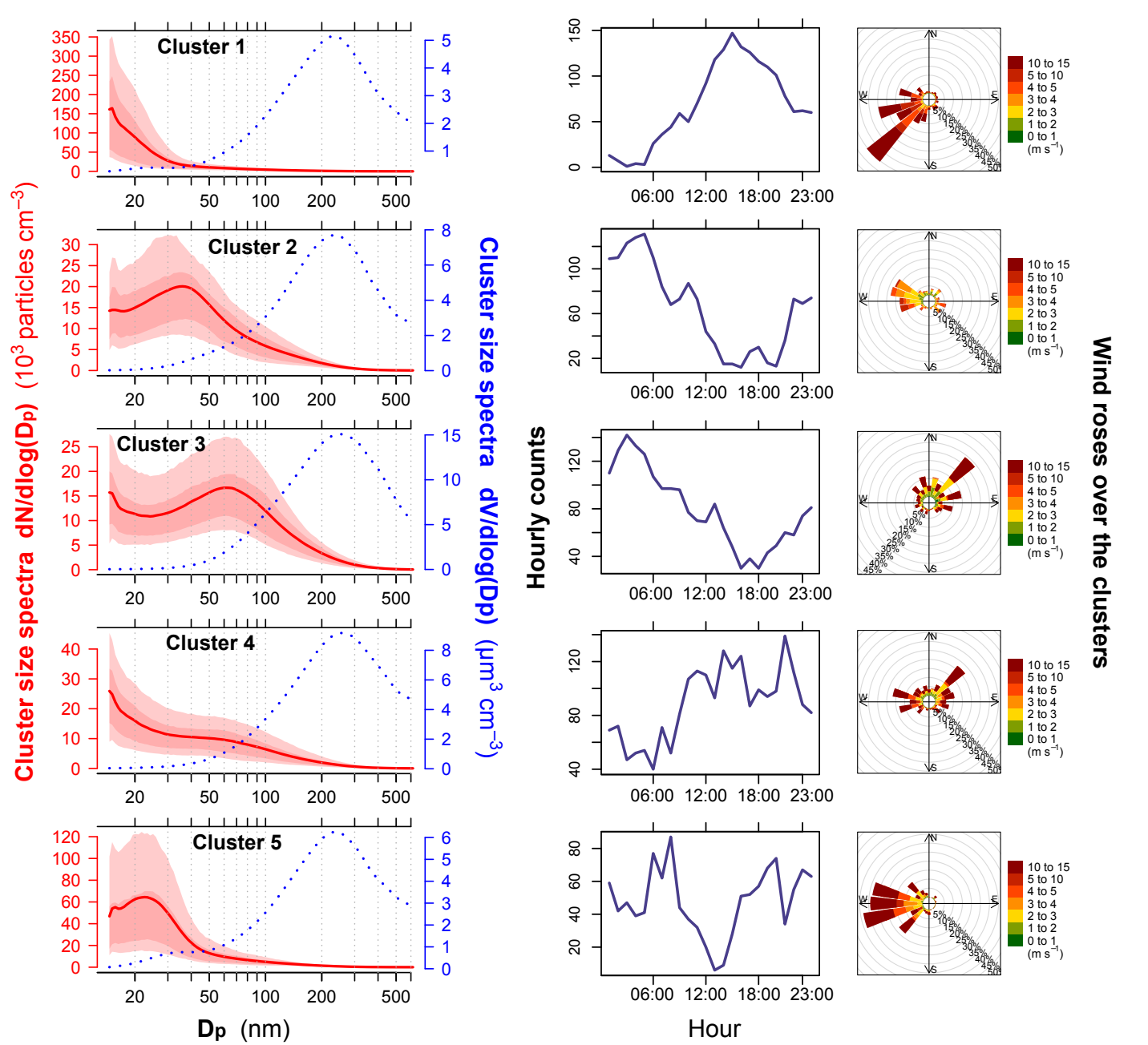

Figure 3. Results of cluster analysis for the warm season data. Average cluster PNSD spectra (left) are reported as solid red lines along with (i) their 10th, 25th, 75th and 90th percentile spectrum as shaded areas, (ii) the volume size distributions (dotted blue line), (iii) the hourly counts, and (iv) the wind roses associated with each cluster.

represent the typical spectra associated with aged anthropogenic emissions, mostly due to road traffic. It is recognised that road traffic contributes to a large range $(30-200 \mathrm{~nm}$ ) of PNSD in the urban atmosphere (e.g. Yue et al., 2008; Costabile et al., 2009; Harrison et al., 2011), which is compatible with these spectra. The directional analysis for the warm season shows increased levels when air masses move from the sectors more affected by traffic, i.e. London (NE), the M4 (N) and M25 (W) motorways, and Tunnel Rd (W), while the hour count profile presents a huge maximum during daytime. In winter, this modal structure mostly occurred for westerly winds: the atmospheric circulation during the cold season mostly experienced winds blowing from the SW quadrant, with NE sectors poorly represented (Fig. SI1). As a consequence, the limited number of observations for air pollution advected from the Greater London area may have affected the detection of the urban background from London. This lack of data is also reflected by diurnal profile, which shows a marked peak in the late afternoon, concurrent to the peak of traffic on the M4 and M25 (Fig. SI5).

Three clusters (clusters 2 and 3 during the warm season and cluster 2 in winter) exhibited similar hourly profiles with most of the counts occurring overnight (Figs. 3 and 4). This pattern is largely attributable to the dynamics of the mixing layer, since the diurnal cycles are the mirror image of the ambient air temperature (Fig. SI4). Because of this, these clusters could be potentially affected by the reduced height of the mixing layer occurring overnight. These clusters exhibit bimodal structures with the coarser modes with respect to the remaining clusters: cluster 2 for the warm season shows a main peak in number concentrations at 30$40 \mathrm{~nm}$ and a second peak in the finest range $(<16 \mathrm{~nm})$, cluster 3 for the warm season peaks at 14 and $60-70 \mathrm{~nm}$, and cluster 2 for the cold season extends over a wide size range with two modes around $20-30 \mathrm{~nm}$ and $100-150 \mathrm{~nm}$. Consequently, these clusters are likely representative of spectra 

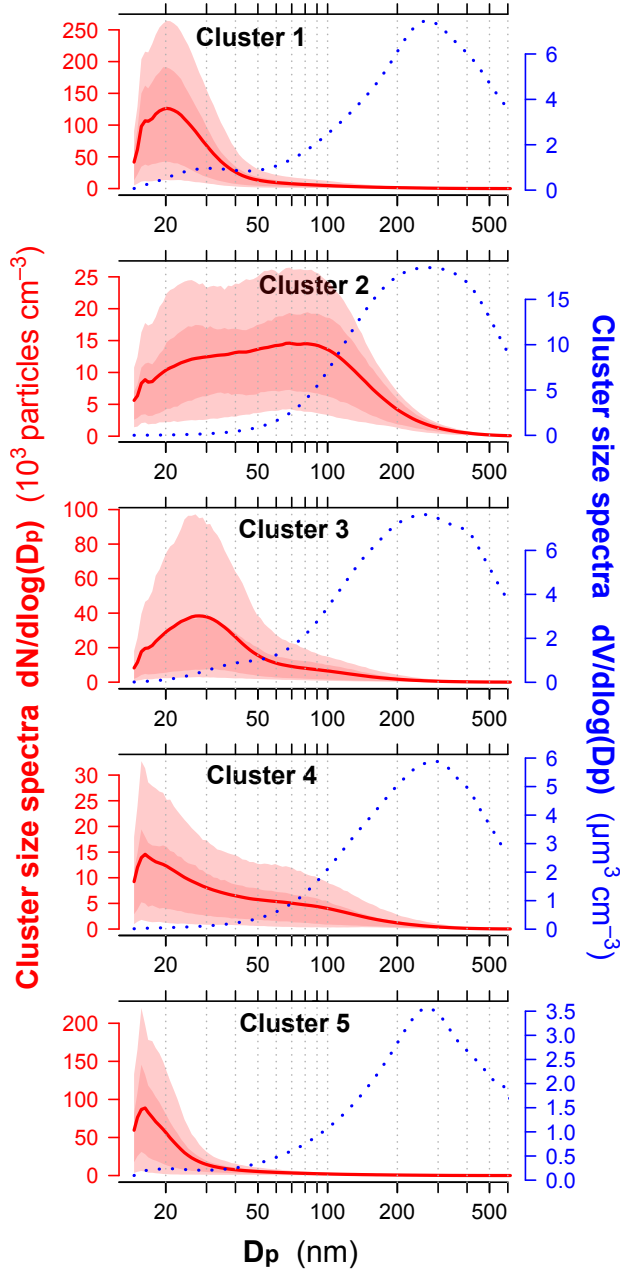
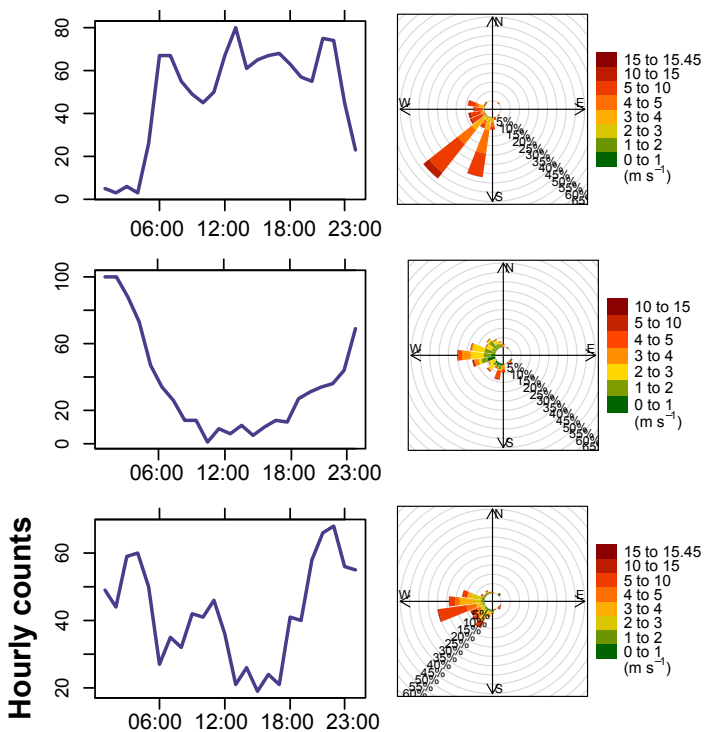

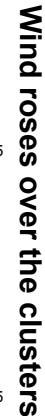
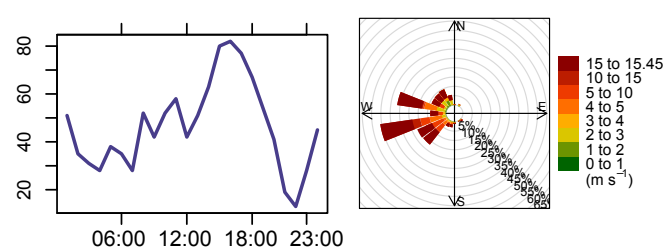

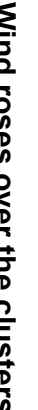
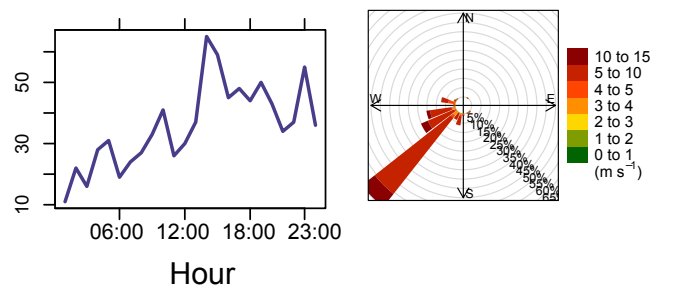

Hour

Figure 4. Results of cluster analysis for the cold season data. Average cluster PNSD spectra (left) are reported as solid red lines along with (i) their 10th, 25th, 75th and 90th percentile spectrum as shaded areas, (ii) the volume size distributions (dotted blue line), (iii) the hourly counts, and (iv) the wind roses associated with each cluster.

mostly shaped by the drop in the mixing layer height and the formation of secondary aerosols. In this context, the potential role of night-time nitrate formation through condensation of $\mathrm{NH}_{4} \mathrm{NO}_{3}$ and the heterogeneous reactions of $\mathrm{N}_{2} \mathrm{O}_{5}$ and $\mathrm{NO}_{3}$ on pre-existing particles cannot be ignored (Seinfeld and Pandis, 2006; Bertram and Thornton, 2009; Brown and Stutz, 2012). The wind roses reveal that both clusters 2 occur under similar westerly wind regimes. Regional aerosols appear to be the most probable source. By contrast, cluster 3 for the warm season occurs with winds from London (NE) and likely represents particle size spectra mainly shaped by primary and secondary aerosols advected from the most urbanised areas, i.e. it is most likely associated with the urban background of London.

Cluster 5 for the warm season and cluster 3 for the cold season may be associated with road traffic. They reveal modal structures with a dominant peak around $20-35 \mathrm{~nm}$ (cluster 5 also shows a possible second peak at $15 \mathrm{~nm}$ ) and mostly occur when air masses blow from westerly sectors, which are compatible with the location of motorways and Tunnel Rd, the main roadway linking LHR to the M4 motorway. In summer, the hourly count pattern exhibits two maxima (06:00-08:00 and 16:00-20:00) related to morning and evening rush hours; this pattern is compatible with fresh road traffic emissions. However, the diurnal pattern in winter also presents a high number of counts at 03:00-05:00, i.e. not directly compatible with rush hours. A possible explanation involves the stronger effect of the winter mixing layer dynamics on the air quality due to the presence of more frequent low-level thermal inversions, which may build up the pollutants at ground level especially overnight. This may increase the signal of the less intense, but still significant, night-time traffic emissions present in the study area. 


\subsection{PMF analysis}

The interpretation of PMF results was then attempted by considering (i) the knowledge of sources impacting the study area, (ii) the comparison with the results reported by $\mathrm{Vu}$ et al. (2016), who performed a PMF analysis of SMPS data collected in North Kensington (London urban background), (iii) the shape of resulting profiles for both the particle number and volume concentrations, (iv) the analysis of diurnal patterns, (v) the directional analysis using the polar plot and polar annuli, (vi) the correlations between the source contributions and the other air pollutants monitored at the site or with weather variables, and (vii) the analysis of possible remote source areas by applying the CWT model.

Six-factor solutions were extracted for both the seasons. The resulting factor profiles are presented in Figs. 5 and 6 for the warm and cold season, respectively. The factor profiles are expressed as (i) particle number concentrations and their DISP ranges, (ii) particle volume concentrations, and (iii) explained variations showing how much of the variance (from 0 to 1) in the original dataset is accounted for by each extracted factor. Figs. 5 and 6 also show the diurnal patterns and the polar plots computed from the hourly-averaged contributions. Table 1 summarises the PMF results and spectral characteristics, while Table 2 shows the Pearson correlation matrices with weather and air quality variables. Selected PMF solutions were very stable: no errors or unmapped factors and few swaps (none in summer and $<7 \%$ in winter) were found in BS; no swaps or errors even at $\mathrm{d} Q_{\max }=25$ were found for DISP - i.e. solutions were affected by small rotational ambiguity, and, therefore, their interpretation can be considered robust.

DISP analysis is designed to explore the realistic bounds on the optimal (base run) PMF solutions that do not result in appreciable increases in the $Q$ values (Brown et al., 2015). In this study, the ranges calculated by DISP for the $\mathrm{d} Q=4$ were used to assess the uncertainty boundaries associated with the final PMF profiles, as suggested in Zikova et al. (2016) and Masiol et al. (2017). This strategy is useful to better interpret the results, as the regions of spectra affected by high rotational ambiguity are disclosed in the resulting profiles.

\subsubsection{Warm season}

Factor 1 includes most of the particles in the nucleation range $(<20 \mathrm{~nm})$, exhibits a sharp mode in the number distribution below the SMPS detection limit $(14 \mathrm{~nm})$ and makes the largest contribution to the total PNC (31.6\%, DISP range of 31-36\%) (Fig. 5). However, its contribution to the volume distribution is $\sim 1 \%$. Several studies report that particles in the nucleation range are emitted from aircraft engines (e.g. Anderson et al., 2005; Herndon et al., 2008; Kinsey et al., 2010; Mazaheri et al., 2009, 2013; Masiol and Harrison, 2014; Lobo et al., 2015, 2012) as well as from other anthropogenic (e.g. Schneider et al., 2005; Chen et al.,
2011; Cheung et al., 2012; Stevens et al., 2012; Kumar et al., 2013, 2014; Vu et al., 2015b) and natural (e.g. Kulmala et al., 1998; O’Dowd et al., 1998, 1999; Kulmala and Kerminen, 2008; Riccobono et al., 2014) sources. This factor does not show any significant $(p<0.05)$ or strong $(r \geq|0.6|)$ correlation with other measured species but shows a weak $(|0.4| \leq r<|0.6|)$ correlation with Factor 2 (Table 2). Its diurnal variation (Fig. 5) shows higher concentrations between 06:00 and 22:00 and agrees well with the airport flight movements (Fig. 2). The polar plot analysis also indicates enhanced levels when winds $>2 \mathrm{~m} \mathrm{~s}^{-1}$ blow from the airfield sectors (SW). All these insights are consistent with the location of Heathrow; i.e. the most plausible interpretation is related to the aircraft engine exhaust emissions. This interpretation is also supported by Keuken et al. (2015), which shows that the PNSD in an area affected by emissions from Schiphol airport (the Netherlands) is dominated by ultrafine (10-20 nm) particles. The large contribution of this factor to the total PNC is not surprising if compared to the results reported for Los Angeles International Airport by Hudda et al. (2014) (emissions from the airport increased PNC 4- to 5 -fold at $8-10 \mathrm{~km}$ downwind of the airfield). Since the airport of Los Angeles and LHR have comparable aircraft traffic, the quite high concentrations found in this study (on annual average nucleation particles are $\sim 10$ times higher than those measured in the North Kensington urban background by $\mathrm{Vu}$ et al. (2016)) are consistent with the sampling location chosen in this study $(\sim 1.2 \mathrm{~km}$ from the airfield). In addition, this result also agrees with previous studies on the impacts of LHR on local air quality; Carslaw et al. (2006) and Masiol and Harrison (2015) found comparable percent contributions of LHR emissions on $\mathrm{NO}_{2}$ levels in the study area (approx. 25-30\%). However, the lack of correlations with NO and $\mathrm{NO}_{2}$ (tracers for aircraft emissions) is probably due to the presence of several other sources of nitrogen oxides in the area, such as the heavy traffic generated from the airport and from the nearby motorways.

Factor 2 is made up of ultrafine particles in the nucleationAitken range (one main peak at $20-35 \mathrm{~nm}$ ) and accounts for $28 \%$ (DISP $25-30 \%$ ) of PNC; its contribution to the volume distribution is low $(\sim 2 \%)$ and peaks at $22-45 \mathrm{~nm}$ and at $140-220 \mathrm{~nm}$ (Fig. 5; Table 1). Several insights seem to link this factor to road traffic emissions: (i) the modal structure, (ii) the strong association with morning and evening rush hours, and (iii) the significant increase for winds in the west and south-westerly sectors consistent with emissions generated from local busy roads close to LHR, Tunnel Rd and the M25 motorway. A similar mode in the nucleation range has been extensively attributed to the size distribution from road traffic (e.g. Vogt et al., 2003; Zhang et al., 2004; Ntziachristos et al., 2007; Vu et al., 2015b) and the growth of nucleation particles from diesel vehicles (Mayer and Ristovski, 2007; Wehner et al., 2009). For example, Charron and Harrison (2003) reported that particles in the range of $30-60 \mathrm{~nm}$ show a stronger association with light-duty traf- 
Table 1. Summary of PMF results for both seasons.

\begin{tabular}{|c|c|c|c|c|}
\hline \multirow{2}{*}{$\begin{array}{l}\text { Factor number and interpretation } \\
\text { Warm season (Aug-Sep 2014) }\end{array}$} & \multicolumn{2}{|c|}{ Particle number concentration } & \multicolumn{2}{|c|}{ Particle volume concentration } \\
\hline & $\begin{array}{l}\text { No. } \text { modes }^{\mathrm{a}} \\
\left(\text { peak ranges }^{\mathrm{b}}\right)\end{array}$ & $\begin{array}{r}\text { Percent contribution } \\
\text { (DISP range) }\end{array}$ & $\begin{array}{l}{\text { No. } \text { modes }^{\mathrm{a}}}\left(\text { peak ranges }^{\mathrm{b}}\right)\end{array}$ & $\begin{array}{r}\text { Percent } \\
\text { contribution }\end{array}$ \\
\hline Factor 1: airport & $1(<20 \mathrm{~nm})$ & $31.6(30.8-36.2)$ & $2(60-160 \mathrm{~nm} ;<25 \mathrm{~nm})$ & 1.2 \\
\hline Factor 2: fresh road traffic & $1(20-35 \mathrm{~nm})$ & $27.9(24.7-30.2)$ & $2(22-45 \mathrm{~nm} ; 140-220 \mathrm{~nm})$ & 1.7 \\
\hline Factor 3: aged road traffic & $1(30-60 \mathrm{~nm})$ & $18.9(16.6-21.1)$ & $2(40-100 \mathrm{~nm} ; 250-450 \mathrm{~nm})$ & 5.6 \\
\hline Factor 4: urban accumulation & $1(50-150 \mathrm{~nm})$ & $14.4(13.8-18)$ & $1(80-250 \mathrm{~nm})$ & 33.2 \\
\hline Factor 5: mixed $\mathrm{SA}^{\mathrm{c}}$ & $1(110-250 \mathrm{~nm})$ & $5.2(3.6-6.9)$ & $1(160-350 \mathrm{~nm})$ & 37.4 \\
\hline Factor 6: inorganic SA & $2(55-120 \mathrm{~nm} ; 230-400 \mathrm{~nm})$ & $2.1(1.1-3.5)$ & $2(260-500 \mathrm{~nm} ; 75-140 \mathrm{~nm})$ & 20.8 \\
\hline \multicolumn{5}{|l|}{ Cold season (Dec 2014-Jan 2015) } \\
\hline Factor 1: airport & $1(<20 \mathrm{~nm})$ & $33.1(31.7-34.8)$ & $2(160-350 \mathrm{~nm} ; 15-25 \mathrm{~nm})$ & 1.7 \\
\hline Factor 2: fresh road traffic & $1(18-35 \mathrm{~nm})$ & $35.2(33.4-36.9)$ & $2(22-45 \mathrm{~nm} ; 150-300 \mathrm{~nm})$ & 3.1 \\
\hline Factor 3: aged road traffic & $1(28-60 \mathrm{~nm})$ & $18.9(17.9-19.7)$ & $2(40-150 \mathrm{~nm} ; 330-450 \mathrm{~nm})$ & 8.7 \\
\hline Factor 4: urban accumulation & $1(55-170 \mathrm{~nm})$ & $7.6(7.3-8.3)$ & $1(100-250 \mathrm{~nm})$ & 32.5 \\
\hline Factor 5: mixed SA & $2(130-280 \mathrm{~nm} ;<17 \mathrm{~nm})$ & $2.3(2.1-3.3)$ & $1(170-400 \mathrm{~nm})$ & 30.8 \\
\hline Factor 6: inorganic SA & $3(17-28 \mathrm{~nm} ; 55-100 \mathrm{~nm} ; 250-400 \mathrm{~nm})$ & $2.9(2.4-3.9)$ & $2(280-550 \mathrm{~nm} ; 90-140 \mathrm{~nm})$ & 23.3 \\
\hline
\end{tabular}

${ }^{a}$ Only modes above the DISP ranges are shown. ${ }^{b}$ Range endpoints are taken at approximately half the mode height. ${ }^{\mathrm{c}}$ SA: secondary aerosol.

fic at a traffic hotspot in central London (Marylebone Rd); Janhäll et al. (2004) reported an average particle size distribution peaking at $15-30 \mathrm{~nm}$ during morning peak high traffic intensity in the city of Göteborg (Sweden), which has a car fleet comparable to the UK; Ntziachristos et al. (2007) found a sharp mode at 20-30 $\mathrm{nm}$ in sampling from engine exhausts. In addition, PMF factors with similar modal structures were found in other studies and were attributed to road traffic emissions: among others, Harrison et al. (2011) linked a factor peaking at $20 \mathrm{~nm}$ to primary road traffic emissions near a major UK highway; Masiol et al. (2016) measured PNSD in an international airport in northern Italy during summer and interpreted a factor with a clear mode at $35-40 \mathrm{~nm}$ as road traffic from the nearby city; Beddows et al. (2015) and $\mathrm{Vu}$ et al. (2016) found traffic factors with modal diameter at around $30 \mathrm{~nm}$ in an urban background site in London (North Kensington); Sowlat et al. (2016) reported a factor peaking at $20-40 \mathrm{~nm}$ in number concentration and at around $30-40 \mathrm{~nm}$ in volume concentration in Los Angeles (US) and interpreted it as traffic tailpipe emissions. However, this factor lacks significant positive correlations with primary road traffic tracers (nitrogen oxides, eBC; Table 2), while other studies have reported weak positive correlations with such species (Harrison et al., 2011; Masiol et al., 2016; Vu et al., 2016; Sowlat et al., 2016). Similarly to Factor 1, this latter result may be due to the difference in the time resolution between chemical species and PNSD and the presence of several sources of nitrogen oxides in the area.

Factor 3 is mostly represented by $25-90 \mathrm{~nm}$ particles and contributes about $19 \%(17-21 \%)$ to the total number concentration (Fig. 5; Table 1). It also shows a second mode below the SMPS detection limit $(14 \mathrm{~nm})$; however, the DISP range clearly indicates that this part of the profile is affected by a large amount of rotational ambiguity, so that the pres- ence of this second mode should be interpreted with caution. The volume concentration peaks at around $40-100 \mathrm{~nm}$ and $250-450 \mathrm{~nm}$. The factor contribution is higher during rush hours, but the morning peak occurs $1 \mathrm{~h}$ later than in Factor 2. The wind directionality shows increases for air masses blowing gently $\left(<4 \mathrm{~m} \mathrm{~s}^{-1}\right)$ from the west and for calm wind periods, suggesting quite a local source; however, an increase in concentrations is also found for higher wind regimes $\left(>6 \mathrm{~m} \mathrm{~s}^{-1}\right)$ from the east (London). Factor 3 also shows significant positive correlations with NO (0.43) and $\mathrm{NO}_{2}$ (0.61) (Table 2). All these insights seem to point to an aged road traffic source. This interpretation is also supported by $\mathrm{Vu}$ et al. (2016), who found a similar factor in London (North Kensington) peaking at $\sim 20-100 \mathrm{~nm}$. In this context, several source apportionment studies on PNSDs have attributed more than one factor to road traffic (e.g. Kasumba et al., 2009; Thimmaiah et al., 2009; Harrison et al., 2011; Liu et al., 2014; Al-Dabbous and Kumar, 2015; Vu et al., 2016; Sowlat et al., 2016). This result is not surprising in areas where heavy traffic is widespread, as particles may undergo condensation, agglomeration, evaporation and dilution processes, and, consequently, they may change modal characteristics in time and space. Such atmospheric processes are the main mechanisms reshaping PNSDs after primary exhaust is emitted into the atmosphere, and they have been discussed in several studies (Shi et al., 1999; Kim et al., 2004; Zhang et al., 2005; Zhou et al., 2005; Kulmala and Kerminen, 2008; Zhang et al., 2011; Harrison et al., 2016).

Factor 4 is made up of particles over a wide range (50$200 \mathrm{~nm}$ with a clear mode at $\sim 80 \mathrm{~nm}$ for PNC and 60 $300 \mathrm{~nm}$ for PVC). The factor contributes $14 \%$ of PNC but accounts for the main percentage of the volume concentration $(33 \%)$. This factor correlates well with gaseous pollutants linked to combustion sources (mostly road traffic), i.e. 
Table 2. Results of Pearson's correlation analysis among extracted factor contributions and other measured variables recorded at different time resolutions. Only correlations significant at $p<0.05$ are reported; strong correlations $(\rho>|0.6|)$ are highlighted in bold. TC: total carbon $(\mathrm{OC}+\mathrm{EC})$

\begin{tabular}{|c|c|c|c|c|c|c|}
\hline \multirow[b]{2}{*}{ variables } & \multicolumn{6}{|c|}{ Warm period } \\
\hline & $\begin{array}{r}\text { Factor } 1 \\
\text { airport }\end{array}$ & $\begin{array}{r}\text { Factor } 2 \\
\text { fresh road } \\
\text { traffic }\end{array}$ & $\begin{array}{r}\text { Factor } 3 \\
\text { aged road } \\
\text { traffic }\end{array}$ & $\begin{array}{r}\text { Factor } 4 \\
\text { urban accu- } \\
\text { mulation }\end{array}$ & $\begin{array}{r}\text { Factor } 5 \\
\text { mixed } \\
\mathrm{SA}\end{array}$ & $\begin{array}{r}\text { Factor } 6 \\
\text { inorganic } \\
\mathrm{SA}\end{array}$ \\
\hline \multicolumn{7}{|c|}{ Weather parameters ( $1 \mathrm{~h}$ resolution time) } \\
\hline Solar irr. & 0.12 & -0.15 & -0.24 & -0.26 & -0.24 & -0.28 \\
\hline Air temp. & 0.25 & -0.21 & -0.37 & -0.1 & 0.1 & \\
\hline RH & & 0.1 & 0.32 & 0.22 & 0.26 & 0.33 \\
\hline Wind speed & 0.38 & & -0.47 & -0.64 & -0.45 & -0.49 \\
\hline \multicolumn{7}{|c|}{5 min resolution time } \\
\hline Factor 1 & - & & & & & \\
\hline Factor 2 & 0.46 & - & & & & \\
\hline Factor 3 & 0.03 & 0.28 & - & & & \\
\hline Factor 4 & -0.17 & -0.04 & 0.47 & - & & \\
\hline Factor 5 & -0.15 & -0.06 & 0.21 & 0.56 & - & \\
\hline Factor 6 & -0.17 & -0.14 & 0.15 & 0.56 & 0.75 & - \\
\hline eBC & -0.1 & -0.03 & 0.33 & 0.62 & 0.52 & 0.53 \\
\hline Delta-C & & & 0.13 & -0.07 & & -0.06 \\
\hline \multicolumn{7}{|c|}{$1 \mathrm{~h}$ resolution time } \\
\hline $\mathrm{NO}$ & & & 0.43 & 0.6 & 0.32 & 0.33 \\
\hline $\mathrm{NO}_{2}$ & & 0.18 & 0.61 & 0.76 & 0.52 & 0.52 \\
\hline $\mathrm{NO}_{x}$ & & 0.11 & 0.58 & 0.77 & 0.48 & 0.48 \\
\hline $\mathrm{O}_{3}$ & 0.14 & -0.19 & -0.57 & -0.54 & -0.37 & -0.43 \\
\hline $\mathrm{PM}_{2.5}$ & -0.23 & -0.24 & 0.13 & 0.61 & 0.63 & 0.77 \\
\hline $\mathrm{NVPM}_{2.5}$ & -0.22 & -0.22 & 0.17 & 0.62 & 0.61 & 0.75 \\
\hline $\mathrm{VPM}_{2.5}$ & -0.17 & -0.24 & & 0.42 & 0.54 & 0.65 \\
\hline \multicolumn{7}{|c|}{1 day resolution time $\mathrm{PM}_{2.5}$-bound species } \\
\hline OC & & & & 0.84 & 0.74 & 0.83 \\
\hline $\mathrm{EC}$ & -0.47 & -0.54 & & 0.75 & 0.51 & 0.67 \\
\hline $\mathrm{TC}$ & -0.45 & -0.44 & & 0.85 & 0.69 & 0.82 \\
\hline \multicolumn{7}{|l|}{ Chloride } \\
\hline Nitrate & & -0.45 & & & 0.83 & 0.85 \\
\hline Sulfate & & -0.57 & & 0.75 & 0.5 & 0.67 \\
\hline Oxalate & & -0.47 & & 0.59 & 0.89 & 0.93 \\
\hline \multicolumn{7}{|l|}{ Sodium } \\
\hline Ammonium & -0.44 & -0.52 & & 0.57 & 0.54 & 0.71 \\
\hline Potassium & & -0.47 & & 0.46 & 0.5 & 0.66 \\
\hline Magnesium & 0.5 & & & -0.53 & & \\
\hline Calcium & & & & & & \\
\hline
\end{tabular}

$\mathrm{NO}(0.6), \mathrm{NO}_{2}(0.76)$ and non-volatile primary pollutants, such as eBC (0.62), NVPM 2.5 (0.62) and EC (0.75) (Table 2). The factor also strongly correlates with OC (0.84) and sulfate $(0.75)$. The diurnal pattern shows two main peaks in the morning and evening rush hours (Fig. 5), but the concentrations recorded between the two maxima are higher overnight than during daytime. This pattern suggests that both local emission sources and the dynamics of the mixing layer may play a key role in shaping its diurnal cycle, i.e. emitted pollutants undergo a wide dispersion within the expanded mixing layer during the daytime, while the drop in the mixing layer top occurring overnight restricts those pollutants to a layer close to ground level. The polar plot indicates increased levels for calm wind conditions or winds blowing from London (east sectors); in addition, the factor is strongly negatively correlated with wind speed $(-0.64)$ (Table 2$)$. 
Table 2. Continued.

\begin{tabular}{|c|c|c|c|c|c|c|}
\hline \multirow[b]{2}{*}{ variables } & \multicolumn{6}{|c|}{ Cold period } \\
\hline & $\begin{array}{r}\text { Factor } 1 \\
\text { airport }\end{array}$ & $\begin{array}{r}\text { Factor } 2 \\
\text { fresh road } \\
\text { traffic }\end{array}$ & $\begin{array}{r}\text { Factor } 3 \\
\text { aged road } \\
\text { traffic }\end{array}$ & $\begin{array}{r}\text { Factor } 4 \\
\text { urban accu- } \\
\text { mulation }\end{array}$ & $\begin{array}{r}\text { Factor } 5 \\
\text { mixed } \\
\text { SA }\end{array}$ & $\begin{array}{r}\text { Factor } 6 \\
\text { inorganic } \\
\mathrm{SA}\end{array}$ \\
\hline \multicolumn{7}{|c|}{ Weather parameters ( $1 \mathrm{~h}$ resolution time) } \\
\hline Solar irr. & & & & -0.11 & & \\
\hline Air temp. & 0.38 & & -0.43 & -0.67 & -0.5 & -0.59 \\
\hline RH & & & 0.23 & 0.38 & 0.46 & 0.46 \\
\hline Wind speed & 0.3 & & -0.49 & -0.67 & -0.54 & -0.61 \\
\hline \multicolumn{7}{|c|}{5 min resolution time } \\
\hline Factor 1 & - & & & & & \\
\hline Factor 2 & 0.55 & - & & & & \\
\hline Factor 3 & 0.24 & 0.54 & - & & & \\
\hline Factor 4 & -0.11 & 0.08 & 0.53 & - & & \\
\hline Factor 5 & -0.05 & 0.15 & 0.38 & 0.65 & - & \\
\hline Factor 6 & -0.09 & 0.08 & 0.39 & 0.7 & 0.81 & - \\
\hline eBC & & 0.16 & 0.52 & 0.77 & 0.60 & 0.63 \\
\hline Delta-C & & & 0.35 & 0.62 & 0.55 & 0.52 \\
\hline \multicolumn{7}{|c|}{$1 \mathrm{~h}$ resolution time } \\
\hline $\mathrm{NO}$ & -0.14 & & 0.51 & 0.81 & 0.62 & 0.63 \\
\hline $\mathrm{NO}_{2}$ & 0.13 & 0.42 & 0.81 & 0.82 & 0.61 & 0.66 \\
\hline $\mathrm{NO}_{x}$ & & 0.17 & 0.63 & 0.85 & 0.64 & 0.68 \\
\hline $\mathrm{O}_{3}$ & & -0.29 & -0.71 & -0.78 & -0.65 & -0.7 \\
\hline $\mathrm{PM}_{2.5}$ & -0.1 & 0.16 & 0.53 & 0.82 & 0.88 & 0.88 \\
\hline $\mathrm{NVPM}_{2.5}$ & -0.11 & 0.16 & 0.53 & 0.82 & 0.85 & 0.85 \\
\hline $\mathrm{VPM}_{2.5}$ & & & 0.19 & 0.39 & 0.49 & 0.48 \\
\hline \multicolumn{7}{|c|}{1 day resolution time $\mathrm{PM}_{2.5}$-bound species } \\
\hline $\mathrm{OC}$ & & & 0.79 & 0.79 & 0.76 & 0.8 \\
\hline $\mathrm{EC}$ & & & 0.83 & 0.8 & 0.64 & 0.66 \\
\hline $\mathrm{TC}$ & & & 0.81 & 0.8 & 0.73 & 0.77 \\
\hline Chloride & & & & 0.58 & 0.82 & 0.85 \\
\hline Nitrate & & 0.63 & 0.73 & 0.88 & 0.93 & 0.9 \\
\hline Sulfate & & & & & 0.92 & 0.88 \\
\hline Oxalate & & & & & 0.87 & 0.81 \\
\hline Sodium & & -0.58 & -0.74 & -0.64 & & \\
\hline Ammonium & & & 0.63 & 0.78 & 0.99 & 0.97 \\
\hline Potassium & & & & 0.71 & 0.98 & 0.97 \\
\hline Magnesium & & & & & & \\
\hline Calcium & & & & & & \\
\hline
\end{tabular}

All these insights suggest that Factor 4 represents the fingerprint of the London pollution. Several studies carried out in London (Beddows et al., 2009, 2015; Vu et al., 2016) and other megacities (e.g. New York: Masiol et al., 2017) have reported similar results, all interpreting this source profile as urban background (or urban accumulation mode). This source comprises both the solid particle mode from traffic emissions (Harrison et al., 2011; Pant and Harrison, 2013; Dall'Osto et al., 2012) and secondary species condensed upon pre-existing particles acting as condensation nuclei, in- cluding secondary sulfate, nitrate and organic aerosols. Secondary sulfate is formed through the atmospheric processing of local or distant $\mathrm{SO}_{2}$ emissions (Kerminen et al., 2000) and neutralisation with ammonia (Benson et al., 2011). Nitrate aerosol is formed through the oxidation of $\mathrm{NO}_{2}$ to nitrate and the consequent neutralisation with ammonia (Seinfeld and Pandis, 2006) and occurs during both daytime and night-time; however, the semi-volatile nature of ammonium nitrate makes its partitioning to the condensed phase very weak. This behaviour also favours the occurrence of negative 

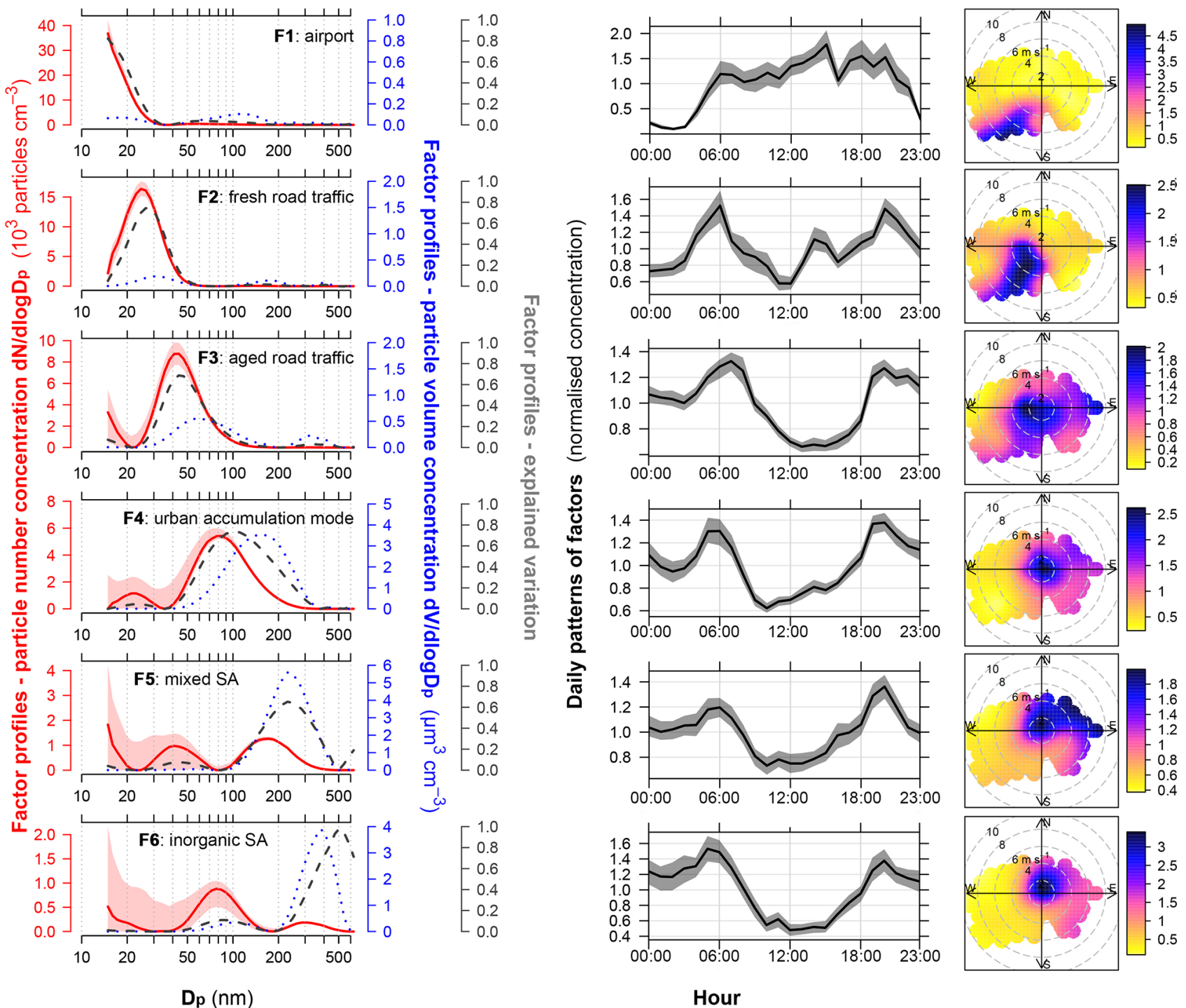

Figure 5. Results of PMF analysis for the warm season data. Factor profiles are reported on the left as (i) number concentration in solid red lines; (ii) their DISP ranges in shaded red areas, (iii) volume concentrations in dotted blue lines; (iv) explained variation in dashed grey lines. The plots in the centre report the normalised daily patterns calculated on the hourly-averaged factor contributions along with their 95th confidence intervals ( $n=200$ bootstrap). The plots on the right show the polar plot analysis (normalised average factor contributions). SA: secondary aerosol.

artefacts in filter-based sampling, which may explain the lack of significant correlations between the factor and the $\mathrm{PM}_{2.5}$ bound nitrate (Table 2). By contrast, the increase in the intensity of Factor 4 during the night-time and the significant association with $\mathrm{NO}_{2}$ are highly consistent with the chemistry driving the heterogeneous reactions of $\mathrm{N}_{2} \mathrm{O}_{5}$ and $\mathrm{NO}_{3}$ on aerosol surfaces (Bertram and Thornton, 2009; Brown and Stutz, 2012). In view of this, Dall'Osto et al. (2009) reported that most nitrate particles in London are (i) locally produced in urban locations during night-time, (ii) mainly present in particles smaller than $300 \mathrm{~nm}$ and (iii) internally mixed with sulfate, ammonium, EC and OC.
Factors 5 and 6 make small contributions to PNC (4-7\% and $1-4 \%$, respectively) but are relevant for the volume concentration (37 and $21 \%$, respectively). Factor 5 shows a main accumulation mode in number concentration at $110-250 \mathrm{~nm}$ and two more modes at $\sim 30-70 \mathrm{~nm}$ and below $14 \mathrm{~nm}$ (Fig. 5; Table 1); however, the latter two modes suffer from large rotational ambiguity and should be interpreted with care. By contrast, it exhibits a wide mode in volume concentration ranging from $\sim 100$ to $\sim 500 \mathrm{~nm}$. Factor 6 has two relevant modes in number concentration at $55-120 \mathrm{~nm}$ and $230-400 \mathrm{~nm}$ and two modes in volume concentration at 260$500 \mathrm{~nm}$ and $75-140 \mathrm{~nm}$. 

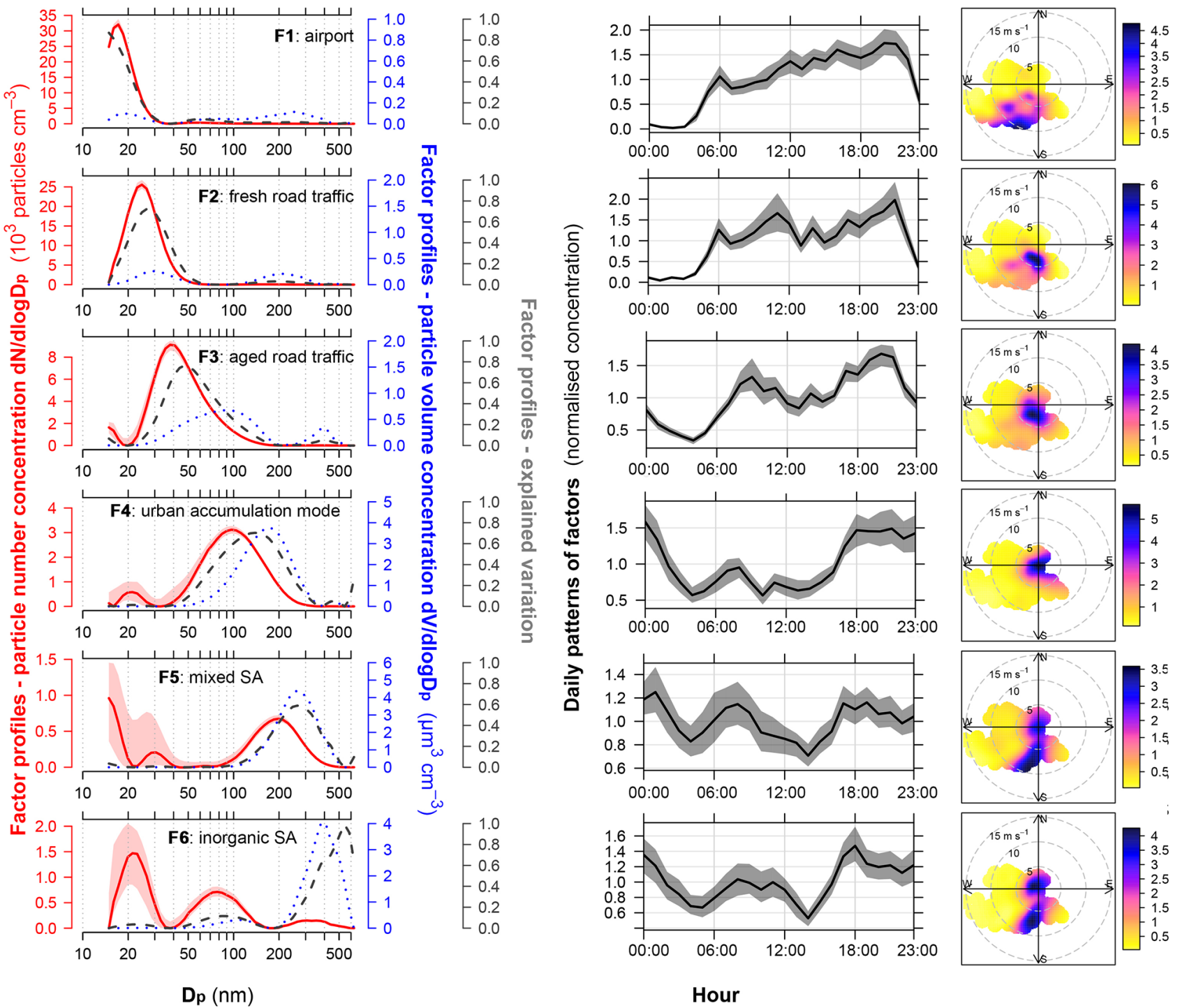

Hour

Figure 6. Results of PMF analysis for the cold season data. Factor profiles are reported on the left as (i) number concentration in solid red lines; (ii) their DISP ranges in shaded red areas, (iii) volume concentrations in dotted blue lines; (iv) explained variation in dashed grey lines. The plots in the centre report the normalised daily patterns calculated on the hourly-averaged factor contributions along with their 95th confidence intervals ( $n=200$ bootstrap). The plots on the right show the polar plot analysis (normalised average factor contributions). SA: secondary aerosol.

These factors still present two peaks corresponding to the rush hours, but the morning peak occurs $1-2 \mathrm{~h}$ earlier than in the road-traffic-related factors, i.e. when ambient temperature reaches its daily minimum. Both factors correlate well with secondary aerosol tracers (nitrate, sulfate, OC) and nonvolatile components (eBC, EC, NVPM 2.5 ), but Factor 6 exhibits much higher correlation coefficients (Table 2). Despite the polar plots indicating the main wind directionality toward the north-east sectors, the analysis of air mass histories though the CWT model (Fig. 7) clearly indicates likely continental origin areas rather than local sources.

$\mathrm{Vu}$ et al. (2016) observed two factors in North Kensington with very similar modal structures, daily patterns, cor- relations with $\mathrm{PM}_{2.5}$-bound species and external source areas maps. Therefore, their interpretation is confirmed also in this study, i.e. mixed secondary aerosol (Factor 5) and inorganic secondary aerosol (Factor 6). Both factors clearly originate in continental Europe and are consistent with a previous receptor modelling study carried out in a rural background site representative of the southern UK (Charron et al., 2013). Similar origin and formation mechanisms also explain their strong correlation (0.75). Although it is not reasonable to extract much more information from these data due to the short period of sampling and the large uncertainty associated with back-trajectory analysis, it can be observed that Factor 5 shows a wide source area all over central Europe, while Fac- 

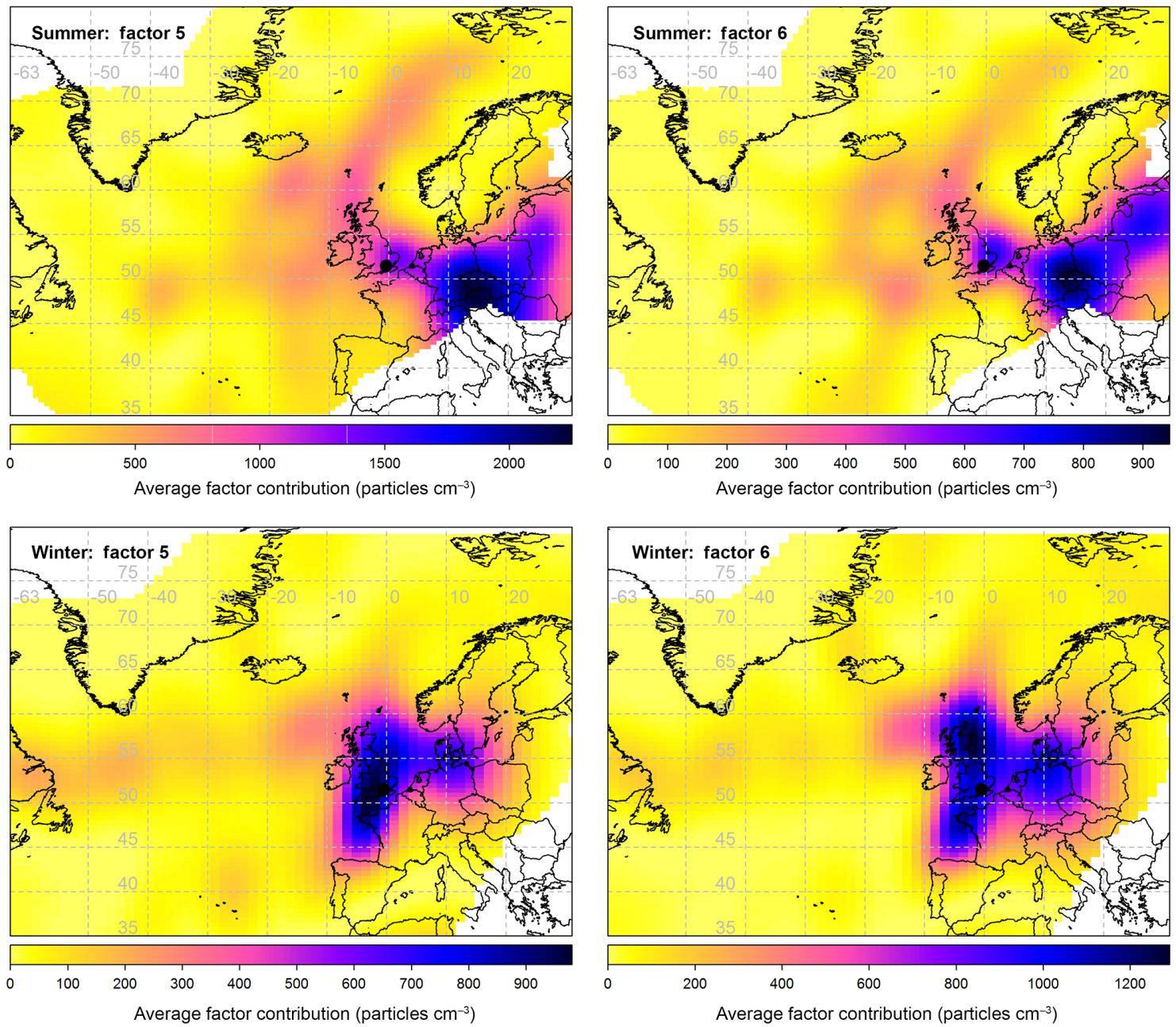

Figure 7. CWT maps of the secondary aerosol-related factors for both the seasons. Map scales refer to the average factor contributions to the total variable (PNC).

tor 6 exhibits two distinct hotspots (central and north-eastern Europe).

\subsubsection{Cold season}

The six factors identified during the cold period (Fig. 6) are similar to those for the warm season. Factor 1 is composed of a high proportion of particles in the nucleation range with a sharp mode at $\sim 15 \mathrm{~nm}$. It accounts for $33 \%(32-35 \%)$ of PNC and less than $2 \%$ of PVC. The polar plot reveals increased concentrations for moderate winds blowing from the airport sector and the diurnal pattern is also compatible with the aircraft traffic. No statistically significant correlations are found with any other monitored species (Table 3). Therefore, Factor 1 may be attributed to the airport emissions related to aircraft engine exhaust. As in the warm season, Factor 1 is moderately correlated with Factor 2 (fresh road traffic, $r=0.55$ ), indicating quite a clear relationship between the two sources.
Factor 2 represents particles in the $15-35 \mathrm{~nm}$ range of number concentration, accounting for $35 \%$ (33-37\%) of total PNC (Fig. 6; Table 1). Its importance for volume concentration is minimal (3\%), with two modes at 30 and $200 \mathrm{~nm}$. The diurnal pattern and the wind directionality are compatible with LHR as a source, and Factor 2 shows a weak positive correlation with $\mathrm{NO}_{2}(0.42)$ and a strong correlation with nitrate (0.63) (Table 3). Despite its similarity and relationship with Factor 1 and the consequent similar potential origin, Factor 2 may represent a different source: factors 1 and 2 remain clearly separated even at solutions down to four factors, demonstrating their structural robustness and the lack of potential artefacts affecting the PMF solution. Consequently, it can be concluded that they to not represent over-resolved solutions (i.e. factor splitting). The most plausible interpretation for Factor 2 is therefore the same as for the warm season, i.e. fresh road traffic emissions. Furthermore, this factor can be attributed to the road traffic generated by the airport and nearby major roads. 
Factor 3 includes most of the particles in the Aitken range and accounts for $19 \%(18-20 \%)$ of PNC. It contribution to particle volume concentration is relevant $(9 \%)$, with a main peak at around $100 \mathrm{~nm}$ and a secondary peak at $400 \mathrm{~nm}$ (Table 1). It presents two rush hours peaks, and the polar plot reveals an origin in the SW quadrant. However, as with the warm period, the wind directionality suggests increases for slower wind regimes rather than the fresh road traffic factor and for more westerly sectors, which are not compatible with the airfield location. Since Factor 3 correlates well (Table 3) with a number of other pollutants linked to primary emissions from road traffic ( $\mathrm{NO}(0.51), \mathrm{NO}_{2}(0.81)$, eBC (0.52), $\mathrm{PM}_{2.5}$ (0.53), OC (0.79) and EC (0.83)), it represents a second road traffic factor, more affected by ageing in the atmosphere than Factor 2.

Despite the wind regimes from the north-east sectors being poorly represented during the cold campaign, Factor 4 is the only one showing a possible origin in London and for calm wind periods. As with the warm season, it is composed of a wide range of particles encompassing the Aitken and accumulation modes (50 to $150 \mathrm{~nm}$ ), while the peak in volume concentration is at $170 \mathrm{~nm}$ (Table 1$)$. The diurnal pattern (Fig. 6) is clearly related to the mixing layer dynamics, and the correlation analysis reveals strong relationships with many species (NO, $\mathrm{NO}_{2}$, eBC, Delta-C, $\mathrm{NVPM}_{2.5}, \mathrm{OC}, \mathrm{EC}$, nitrate, ammonium and potassium; Table 3). Consequently, it is concluded that it represents the urban accumulation mode, whose contribution to the total volume concentration is also similar to the warm season $(33 \%)$. It is interesting to note the large similarity with the urban accumulation mode found in the warm season, from which it differs slightly only in the diurnal pattern (higher overnight) and in the presence of a strong correlation with nitrate $(r=0.88)$, possibly due to the lesser extent of negative artefacts in $\mathrm{PM}_{2.5}$ filter samples.

The last two factors are interpreted as due to secondary aerosols. Their modal structures, their contributions to total PNC and PVC, and their correlations with $\mathrm{PM}_{2.5}$-bound species (Table 3; Fig. 6) largely reflect the results obtained for the warm period. However, the CWT maps (Fig. 7) highlight different source areas; i.e. the origin of the secondary aerosols is regional (UK and northern Europe). In addition, the presence of strong positive correlations with chloride may also indicate a contribution from the transport of seasalt aerosol.

\subsection{Comparison of $k$ means and PMF}

The cluster analysis revealed the presence of five characteristic PNSD shapes during both the seasons. These spectra have been linked to potential sources in the study area, i.e. road traffic, airport activities and secondary aerosol formation processes. However, the cluster analysis is mostly driven by the spectral size regions with higher particle number concentrations; i.e. it has the disadvantage of partitioning the single observations predominantly according to the finest re- gion of the size distribution. This limitation is well illustrated by the poor (almost null) separation of clusters based on the particle volume distributions (all clusters showed quite similar particle volume spectra). In addition, cluster analysis also has the disadvantage of linking each cluster to a single source and does not easily account for PNSD resulting from the mix of two or more different sources.

In contrast, the PMF analysis computed over the PNSD also accounts well for the sources, with a small impact on the number distribution but having a larger influence on the particle volume size distributions and, therefore, on the particle mass concentration. Despite the differences in the two methods, some further information can be extracted by combining the results of cluster and PMF analysis. Figure 8 shows the statistics of normalised PMF source contributions relating to each single cluster.

For the warm period, significantly higher (0.05 significance) PMF contributions of the airport factor (F1) are measured for cluster 1 (average normalised contribution $\sim 3.5$ ). This result indicates that the airport fingerprint was well captured by both source apportionment methods. During the cold season, the airport factor (F1) is significantly higher for both clusters 1 and 5 (average normalised contributions of $\sim 2$ and $\sim 3$, respectively). While cluster 5 presents significant high PMF contributions only for Factor 1, cluster 1 also shows high contributions of Factor 2 (fresh road traffic). This result indicates that cluster 5 may represent the typical PNSD spectra for airport emissions, while cluster 2 likely represents mixed emissions from aircraft and airport-related traffic. A close analysis of wind roses for the two clusters in the cold season (Fig. 4) reveals that cluster 5 occurs in significantly higher wind speed regimes than cluster 1 (MannWhitney-Wilcoxon test at 0.05 significance level), i.e. average wind speeds of 8.3 and $5.9 \mathrm{~m} \mathrm{~s}^{-1}$, respectively. As a consequence, the different wind regimes may well be responsible for the split between the two clusters.

Results for fresh traffic emissions also agree between the two methods. Factor 2 exhibits the higher normalised contributions to clusters 5 (normalised contribution 2.5) and 1 (normalised contribution $\sim 3$ ) for the warm and cold period, respectively (Fig. 8). However, in winter it is evident that PNSDs grouped on cluster 1 are also strongly influenced by airport emissions, probably due to the lower mixing layer height and, thus, a lesser dispersion in the atmosphere.

Cluster 4 for both the periods shows enrichments in the contributions for four PMF sources (aged road traffic, urban accumulation and the two secondary aerosols) (Fig. 8). This further emphasises that cluster 4 represents the typical PNSD during daytime resulting from the mixing of different sources. In a similar way, clusters 3 and 2 in the warm and cold periods, respectively, represent the typical night-time spectra (Figs. 3 and 4); i.e. they exhibit similar partitioning over the PMF sources and similar daily cycles. 

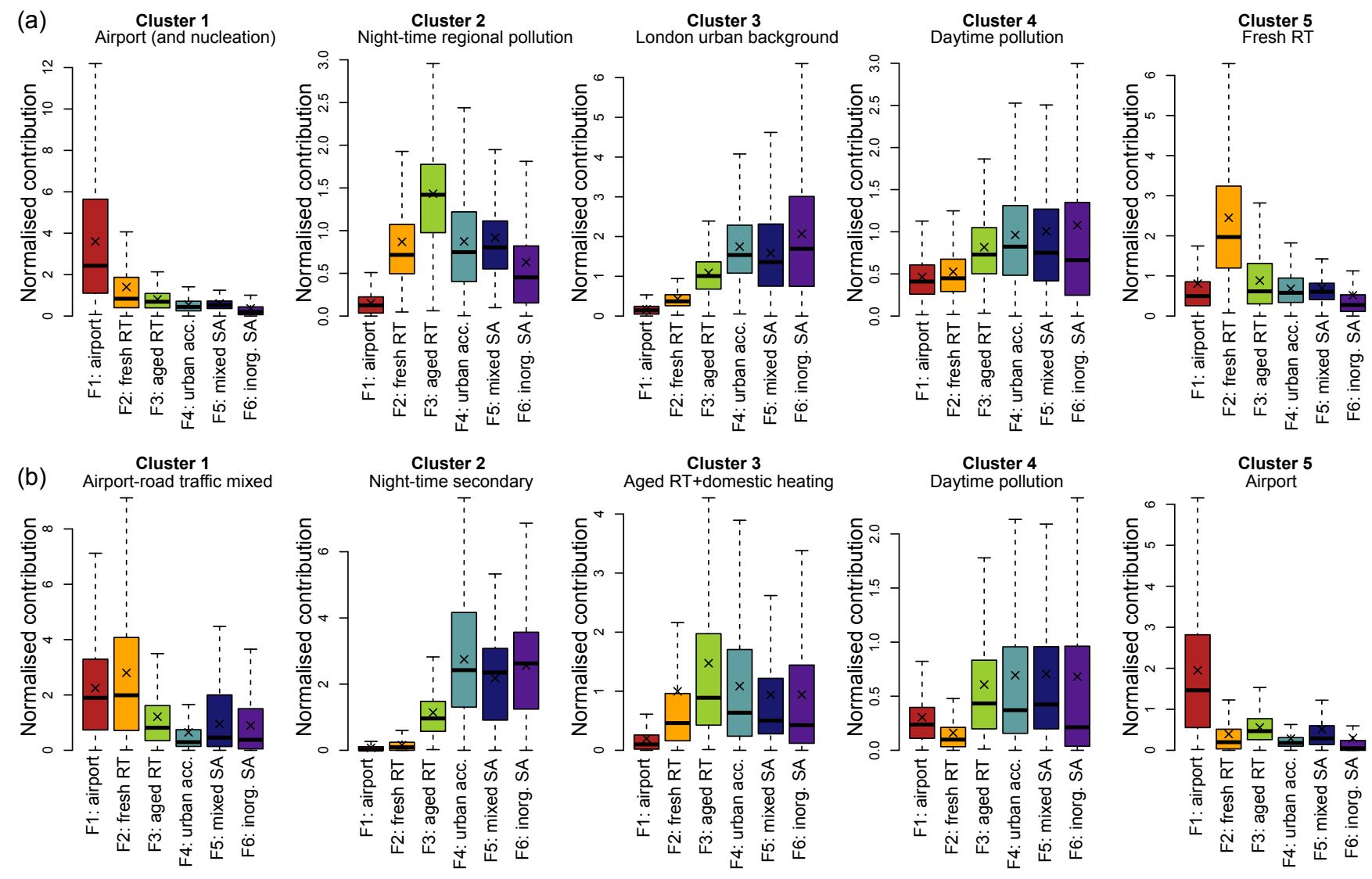

Figure 8. Comparison of $k$ means and PMF for the warm (a) and cold (b) seasons. Boxplot statistics: lines - medians; crosses - arithmetic means; boxes -25 th -75 th percentile ranges; whiskers $- \pm 1.5 \times$ interquartile ranges.

\subsection{Analysis of a large regional nucleation event}

Regional photochemical nucleation episodes are regularly recorded in the southern and eastern UK. Their general characteristics have been reported in a number of studies (e.g. Alam et al., 2003; Charron et al., 2007, 2008; Beddows et al., 2015; Vu et al., 2016) and can be summarised as follows: (i) particle modality at around $20 \mathrm{~nm}$, (ii) higher frequency around noon in association with the peak in actinic flux intensities, (iii) clear seasonal cycles (higher average contribution levels in the summer, from June to September) and (iv) marked directionality from the westerly sectors, reflecting maritime atmospheric circulation regimes, with high wind speed and low $\mathrm{PM}_{2.5}$ concentrations.

A strong regional nucleation event occurred during the warm-period sampling campaign (starting on 7 September at 13:00 UTC and lasting for about $12 \mathrm{~h}$ ). Increases in PNC were almost simultaneously recorded at Harlington and at Harwell, a national network rural background site located approx. $60 \mathrm{~km}$ west-north-west of LHR and representative of the regional background levels of air pollution across the southern UK. The comparison of PNC time series at the two sites is provided as Fig. SI10. Figure 9 shows the con- tour plots of SMPS data recorded at Harlington between 7 and 8 September as well as the hourly averaged concentrations of nucleation, Aitken and accumulation particles, TEOM-FDMS $\mathrm{PM}_{2.5}$ mass, and the contributions of factor 1 to 4 extracted by the PMF. Figure 9 also reports the hourly counts of the number of clusters extracted by the $k$ means analysis. The contour plot shows a typical "banana" shape with particle mode growing from $\sim 20 \mathrm{~nm}$ (13:00) to $\sim 100 \mathrm{~nm}$ (overnight). The episode strongly influenced the PNSDs until around midnight; however, its effect is also visible over the first half of 8 September. The time series (Fig. 9) exhibits a clear peak in nucleation particles between 13:00 and 15:00 followed by peaks of Aitken- (15:00-23:00) and accumulation-mode (20:00-02:00) particles. The backtrajectory analysis (Fig. SI11) revealed that the event occurred when north-westerly fresh (and clean) maritime air masses were advected from the Atlantic. This is also supported by the $\mathrm{PM}_{2.5}$ mass, which exhibited a fast drop in concentrations just a few hours before the event $\left(-30 \mu \mathrm{g} \mathrm{m}^{-3}\right.$ in $3 \mathrm{~h}$, i.e. from $40 \mu \mathrm{g} \mathrm{m}^{-3}$ at $06: 00$ to $10 \mu \mathrm{g} \mathrm{m}^{-3}$ at 09:00; Fig. 9), probably reducing the condensation sink and facilitating nucleation. 


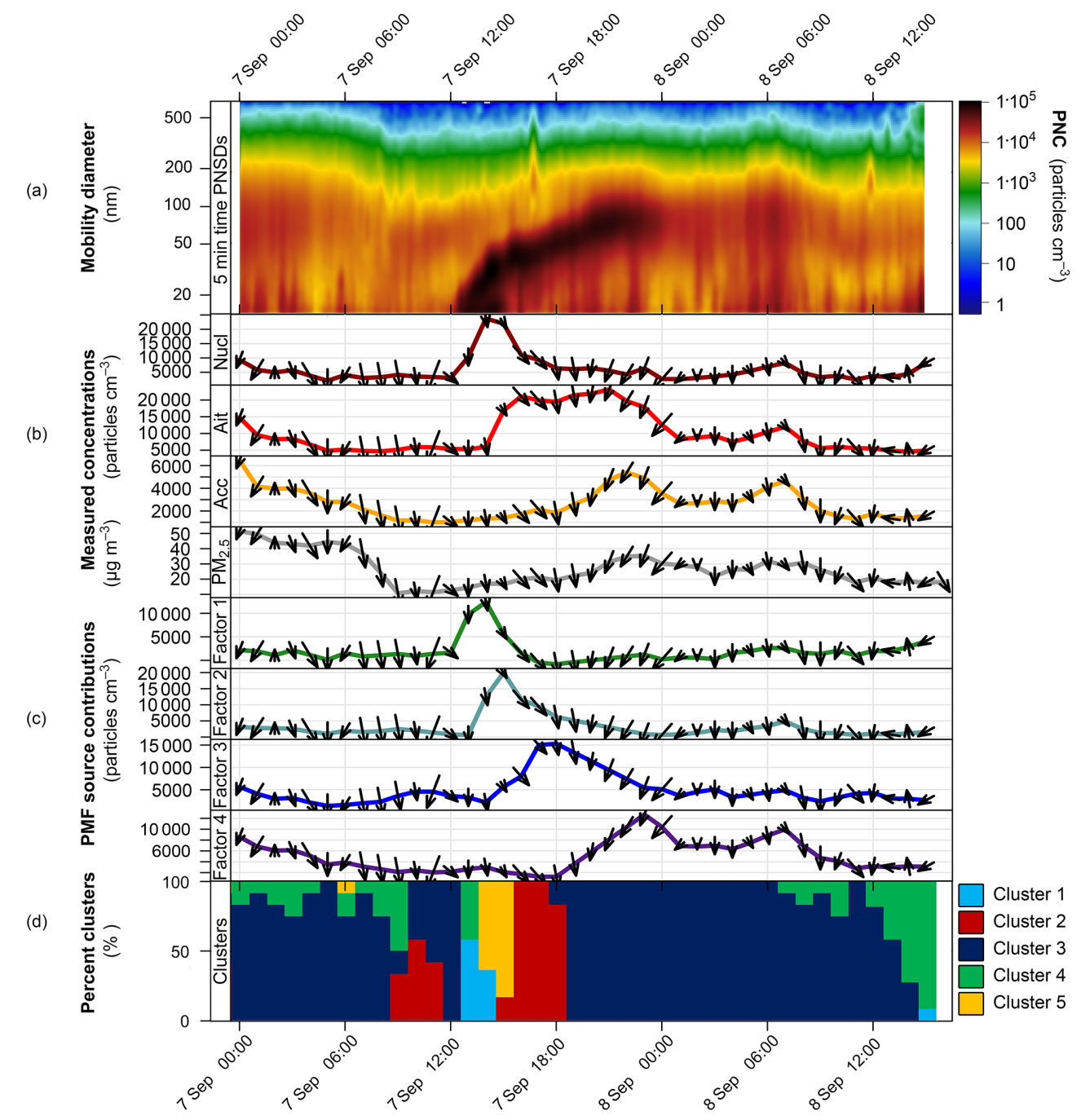

Figure 9. Analysis of the regional nucleation episode occurring on 7 September. The selected period is from 7 September midnight to 8 September 16:00. The plots represent (from upper to the bottom) (a) contour plots of SMPS data; (b) concentrations of some measured species (Nucl: particles in the nucleation range of 14-30 nm; Ait: particles in the Aitken nuclei range of 30-100 nm; Acc: particles in the accumulation range $>100 \mathrm{~nm}$; mass of $\mathrm{PM}_{2.5}$ ); (c) source contributions from PMF for the factors 1, 2, 3 and 4; (d) hourly counts of the number of clusters. The arrows in (b) and (c) show the wind direction (arrow direction) and speed (proportional to arrow length).

Both atmospheric nucleation and aircraft engines are recognised to produce particles in the nucleation range. The analysis of this single - but strong - episode gives insights into how much the source apportionment results can potentially be affected by regional nucleation. This latter analysis is possible because the wind directionality during the entire episode was from northern sectors; i.e. the contribution of LHR can be considered negligible.

The results of cluster analysis were affected by the event. Before the episode, the PNSD spectra were mostly categorised as clusters 3 and 4 (urban background and daytime pollution, respectively), i.e. the clusters mostly recorded under north-easterly wind regimes (Fig. 3). About 50 and $30 \%$ of the clusters were then categorised as "airport" in the first and second hour of the episode, respectively (Fig. 9). Since the wind directionality is inconsistent with an origin in the airfield, this categorisation is likely the result of the nucleation event. The growing of particles in the hours after the beginning of the event has further driven the cluster results: (i) about 60-80\% of PNSDs were categorised as "fresh road traffic" (cluster 5) after 2-3h, and (ii) $80-100 \%$ of PNSDs were clustered as "night-time regional pollution" (cluster 2) after 4-6h. In a similar way, PMF results were affected by the event (Fig. 9), with a sharp increase in contribution levels for (i) Factor 1 (airport) from $1.5 \times 10^{3}$ particles $\mathrm{cm}^{-3}$ at noon to $13.3 \times 10^{3}$ particles $\mathrm{cm}^{-3}$ at 14:00, (ii) Factor 2 (fresh road traffic) from $0.5 \times 10^{3}$ particles $\mathrm{cm}^{-3}$ at 13:00 to $21 \times 10^{3}$ particles $\mathrm{cm}^{-3}$ at 15:00 and (iii) Factor 3 (aged road traffic) from $2.1 \times 10^{3}$ particles $\mathrm{cm}^{-3}$ at 14:00 to approx. $15 \times 10^{3}$ particles $\mathrm{cm}^{-3}$ at 17:00-18:00. 
This episode was the main nucleation event recorded during the two sampling campaigns. Other possible episodes also occurred (mostly during the warm season), but they were much less significant and often hard to detect. This qualitative analysis points to some conclusions: (i) regional photochemical nucleation events may have an effect on clustering and PMF results, (ii) the effect may lead to an "additive" bias, mostly over the airport and road traffic factors and clusters, and (iii) the effect of regional nucleation events in the study area is largely overwhelmed by the strength of local sources, but in other locations with more frequent nucleation events it may be more important to identify and separate them.

\section{Conclusions}

The effect of airport emissions upon the particle number concentration and size distribution was assessed at a site close to a major European airport (Heathrow) serving a megacity (London). The conclusions to be drawn are as follows.

- High particle number concentrations were recorded for the finest sizes (nucleation $<30 \mathrm{~nm}$ and Aitken nuclei $30-100 \mathrm{~nm}$ ) if compared to an urban background site in London (North Kensington).

- Polar plot analysis indicates that Heathrow is a strong potential source for $\mathrm{NO}_{2}$, nucleation and Aitken particles, but its contribution to the mass concentration of $\mathrm{PM}_{2.5}$ and eBC is very small. By contrast, the urban area of London appears to be the main source for PM and $\mathrm{eBC}$.

- The $k$ means cluster analysis has revealed that $20 \%$ of PNSDs are mostly shaped by airport direct emissions, but particle size spectra are also strongly affected by other local sources (mostly fresh and aged road traffic during daytime) and the reduction in mixing layer depth (during night-time). Typical PNSD spectra have been identified for night-time and daytime pollution as well. Such spectra are likely the result of multiple source mixtures.

- PMF analysis revealed that the fingerprint of Heathrow has a peculiar modal structure peaking at $<20 \mathrm{~nm}$. The direct airport emissions account for $30-35 \%$ of total particles in both the seasons. Such results are in line with percent estimations for $\mathrm{NO}_{2}$ reported in previous studies.

- Other major contributors to PNC are fresh (24-36\%) and aged (16-21\%) road traffic emissions. Despite both applied source apportionment methods failing to fully disaggregate the emissions from the local traffic (including motorway) and traffic generated by the airport, results suggest that road traffic sources may contribute to the total PNC more than Heathrow (40-56\%). However, making a clear distinction between the influence of traffic generated by the airport from other road traffic is not feasible from this analysis.

- An urban accumulation mode was found. This source presents a wide mode between $50-150 \mathrm{~nm}$ and accounts for around $10 \%$ of PNC. The wind directionality is consistent with the advection of air masses from London. It is more evident overnight due to the drop in the mixing layer top, the subsequent increase in air pollutants at ground level and the generation of night-time secondary nitrate aerosols.

- Secondary sources accounted for less than $6 \%$ in number concentrations but for more than $50 \%$ in volume concentration. Long-range transport has a key role in advecting polluted air masses from mainland Europe.

Data availability. Data are available from the authors (mmasiol@clarkson.edu) upon request.

Competing interests. The authors declare that they have no conflict of interest.

\section{The Supplement related to this article is available online at https://doi.org/10.5194/acp-17-12379-2017- supplement.}

Acknowledgements. The authors gratefully acknowledge (i) the European Union for funding the Marie Curie Intra-European Fellowship for career development to Mauro Masiol through the project "CHEERS" (Chemical and Physical Properties and Source Apportionment of Airport Emissions in the context of European Air Quality Directives; call: FP7-PEOPLE-2012-IEF; project no. 328542), (ii) the Natural Environment Research Council for support of David Beddows under award R8/H12/83/2017/18, (iii) Heathrow Airport Ltd and Ricardo-AEA for supplying aircraft movement data and for the valuable exchange of information and discussion, in particular Katherine Rolfe, Elizabeth Hegarty (Heathrow), Brian Stacey (Ricardo-AEA) and David Vowles, (iv) DEFRA Automatic Urban and Rural Network and London Air Quality Network for providing pollutant data, (v) the Met Office and BADC for weather data, (vi) the NOAA Air Resources Laboratory (ARL) for the provision of the HYSPLIT transport and dispersion model used in this publication, (vii) the UK Department for Transport, Road Traffic and Road Freight Statistics for providing M4 and M25 traffic data, and (viii) Stefania Squizzato (University of Rochester, NY, USA) for the valuable exchange of information.

Edited by: Andreas Petzold

Reviewed by: two anonymous referees 


\section{References}

ACI (Airport Council International): ACI releases preliminary world airport traffic rankings. Airports Council International, Montreal, available at: http: //www.aci.aero/News/Releases/Most-Recent/2016/04/04/ ACI-releases-preliminary-world-airport-traffic-rankings- (last access: 2 October 2017), 2016.

AEA: Heathrow Airport Air Quality Modelling for 2008/9: Results and Model Evaluation. Report by AEA Energy \& Environment on behalf of BAA, AEAT/ENV/R/2948/Issue 1, London, Heathrow Airport Ltd, July 2010.

Al-Dabbous, A. N. and Kumar, P.: Source apportionment of airborne nanoparticles in a Middle Eastern city using positive matrix factorization, Environ. Sci.-Proc. Imp., 17, 802-812, 2015.

Alam, A., Shi, J. P., and Harrison, R. M.: Observations of new particle formation in urban air, J. Geophys. Res.-Atmos., 108, 40934107, https://doi.org/10.1029/2001JD001417, 2003.

Anderson, B. E., Branham, H.-S., Hudgins, C. H., Plant, J. V., Ballenthin, J. O., Miller, T. M., Viggiano, A. A., Blake, D. R., Boudries, H., Canagaratna, M., Miake-Lye, R. C., Onasch, T., Wormhoudt, J., Worsnop, D., Brunke, K. E., Culler, S., Penko, P., Sanders, T., Han, H.-S., Lee, P., Pui, D. Y. H., Thornhill, K. L., and Winstead, E. L.: Experiment to Characterize Aircraft Volatile Aerosol and Trace-Species Emissions (EXCAVATE), NASA/TM-2005-213783, National Aeronautics and Space Administration, Hampton, VA, 2005.

Atkinson, R. W., Fuller, G. W., Anderson, H. R., Harrison, R. M., and Armstrong, B.: Urban ambient particle metrics and health: a time-series analysis, Epidemiology, 21, 501-511, 2010.

Beddows, D. C. S., Dall'Osto, M., and Harrison, R. M.: Cluster analysis of rural, urban and curbside atmospheric particle size data, Environ. Sci. Technol., 43, 4694-4700, 2009.

Beddows, D. C. S., Dall'Osto, M., Harrison, R. M., Kulmala, M., Asmi, A., Wiedensohler, A., Laj, P., Fjaeraa, A. M., Sellegri, K., Birmili, W., Bukowiecki, N., Weingartner, E., Baltensperger, U., Zdimal, V., Zikova, N., Putaud, J.-P., Marinoni, A., Tunved, P., Hansson, H.-C., Fiebig, M., Kivekäs, N., Swietlicki, E., Lihavainen, H., Asmi, E., Ulevicius, V., Aalto, P. P., Mihalopoulos, N., Kalivitis, N., Kalapov, I., Kiss, G., de Leeuw, G., Henzing, B., O’Dowd, C., Jennings, S. G., Flentje, H., Meinhardt, F., Ries, L., Denier van der Gon, H. A. C., and Visschedijk, A. J. H.: Variations in tropospheric submicron particle size distributions across the European continent 2008-2009, Atmos. Chem. Phys., 14, 4327-4348, https://doi.org/10.5194/acp-14-4327-2014, 2014.

Beddows, D. C. S., Harrison, R. M., Green, D. C., and Fuller, G. W.: Receptor modelling of both particle composition and size distribution from a background site in London, UK, Atmos. Chem. Phys., 15, 10107-10125, https://doi.org/10.5194/acp-15-101072015, 2015.

Belis, C. A., Larsen, B. R., Amato, F., El Haddad, I., Favez, O., Harrison, R. M., Hopke, P. K., Nava, S., Paatero, P., Prévôt, A., Quass, U., Vecchi, R., and Viana, M.: European Guide on Air Pollution Source Apportionment with Receptor Models, JRC Reference Reports EUR26080 EN, Luxembourg, Publications Office of the European Union, 2014.

Benson, D. R., Yu, J. H., Markovich, A., and Lee, S.-H.: Ternary homogeneous nucleation of $\mathrm{H}_{2} \mathrm{SO}_{4}, \mathrm{NH}_{3}$, and $\mathrm{H}_{2} \mathrm{O}$ under conditions relevant to the lower troposphere, Atmos. Chem. Phys., 11, 4755-4766, https://doi.org/10.5194/acp-11-4755-2011, 2011.
Bertram, T. H. and Thornton, J. A.: Toward a general parameterization of $\mathrm{N}_{2} \mathrm{O}_{5}$ reactivity on aqueous particles: the competing effects of particle liquid water, nitrate and chloride, Atmos. Chem. Phys., 9, 8351-8363, https://doi.org/10.5194/acp-9-8351-2009, 2009.

Brines, M., Dall'Osto, M., Beddows, D. C. S., Harrison, R. M., and Querol, X.: Simplifying aerosol size distributions modes simultaneously detected at four monitoring sites during SAPUSS, Atmos. Chem. Phys., 14, 2973-2986, https://doi.org/10.5194/acp14-2973-2014, 2014.

Brines, M., Dall'Osto, M., Beddows, D. C. S., Harrison, R. M., Gómez-Moreno, F., Núñez, L., Artíñano, B., Costabile, F., Gobbi, G. P., Salimi, F., Morawska, L., Sioutas, C., and Querol, X.: Traffic and nucleation events as main sources of ultrafine particles in high-insolation developed world cities, Atmos. Chem. Phys., 15, 5929-5945, https://doi.org/10.5194/acp15-5929-2015, 2015.

Brown, S. S. and Stutz, J.: Nighttime radical observations and chemistry, Chem. Soc. Rev., 41, 6405-6447, 2012.

Brown, S. G., Eberly, S., Paatero, P., and Norris, G. A.: Methods for estimating uncertainty in PMF solutions: examples with ambient air and water quality data and guidance on reporting PMF results, Sci. Total Environ., 518, 626-635, 2015.

Carslaw, D. C. and Ropkins, K.: Openair - an R package for air quality data analysis, Environ. Modell. Softw., 27-28, 52-61, 2012.

Carslaw, D. C., Beevers, S. D., Ropkins, K., and Bell, M. C.: Detecting and quantifying aircraft and other on-airport contributions to ambient nitrogen oxides in the vicinity of a large international airport, Atmos. Environ., 40, 5424-5434, 2006.

Carslaw, D. C., Beevers, S. D., and Bell, M. C.: Risks of exceeding the hourly EU limit value for nitrogen dioxide resulting from increased road transport emissions of primary nitrogen dioxide, Atmos. Environ., 41, 2073-2082, 2007.

Charron, A. and Harrison, R. M.: Primary particle formation from vehicle emissions during exhaust dilution in the roadside atmosphere, Atmos. Environ., 37, 4109-4119, 2003.

Charron, A., Birmili, W., and Harrison, R. M.: Factors influencing new particle formation at the rural site, Harwell, UK, J. Geophys. Res.-Atmos., 112, D14210, https://doi.org/10.1029/2007JD008425, 2007.

Charron, A., Birmili, W., and Harrison, R. M.: Fingerprinting particle origins according to their size distribution at a UK rural site, J. Geophys. Res.-Atmos., 113, D07202, https://doi.org/10.1029/2007JD008562, 2008.

Charron, A., Degrendele, C., Laongsri, B., and Harrison, R. M.: Receptor modelling of secondary and carbonaceous particulate matter at a southern UK site, Atmos. Chem. Phys., 13, 1879-1894, https://doi.org/10.5194/acp-13-1879-2013, 2013.

Chen, J.-P., Tsai, T.-S., and Liu, S.-C.: Aerosol nucleation spikes in the planetary boundary layer, Atmos. Chem. Phys., 11, 71717184, https://doi.org/10.5194/acp-11-7171-2011, 2011.

Cheung, H. C., Morawska, L., Ristovski, Z. D., and Wainwright, D.: Influence of medium range transport of particles from nucleation burst on particle number concentration within the urban airshed, Atmos. Chem. Phys., 12, 4951-4962, https://doi.org/10.5194/acp-12-4951-2012, 2012. 
Clapp, L. J. and Jenkin, M. E.: Analysis of the relationship between ambient levels of $\mathrm{O}_{3}, \mathrm{NO}_{2}$ and $\mathrm{NO}$ as a function of $\mathrm{NO}_{x}$ in the UK, Atmos. Environ., 35, 6391-6405, 2001.

Costabile, F., Birmili, W., Klose, S., Tuch, T., Wehner, B., Wiedensohler, A., Franck, U., König, K., and Sonntag, A.: Spatiotemporal variability and principal components of the particle number size distribution in an urban atmosphere, Atmos. Chem. Phys., 9, 3163-3195, https://doi.org/10.5194/acp-9-3163-2009, 2009.

Dall'Osto, M., Thorpe, A., Beddows, D. C. S., Harrison, R. M., Barlow, J. F., Dunbar, T., Williams, P. I., and Coe, H.: Remarkable dynamics of nanoparticles in the urban atmosphere, Atmos. Chem. Phys., 11, 6623-6637, https://doi.org/10.5194/acp11-6623-2011, 2011.

Dall'Osto, M., Beddows, D. C. S., Pey, J., Rodriguez, S., Alastuey, A., Harrison, R. M., and Querol, X.: Urban aerosol size distributions over the Mediterranean city of Barcelona, NE Spain, Atmos. Chem. Phys., 12, 10693-10707, https://doi.org/10.5194/acp-12-10693-2012, 2012.

DEFRA: Air Pollution in the UK 2015. UK Department for Environment, Food and Rural Affairs. Issue of September 2016. Available at: https://uk-air.defra.gov.uk/assets/documents/ annualreport/air_pollution_uk_2015_issue_1.pdf (last access: 2 October 2017), 2016.

Dodson, R. E., Houseman, E. A., Morin, B., and Levy, J. I.: An analysis of continuous black carbon concentrations in proximity to an airport and major roadways, Atmos. Environ., 43, 37643773, 2009.

Farias, F. and ApSimon, H.: Relative contributions from traffic and aircraft $\mathrm{NO}_{x}$ emissions to exposure in West London, Environ. Modell. Softw., 21, 477-485, 2006.

Harrison, R. M., Beddows, D. C. S., and Dall'Osto, M.: PMF Analysis of wide-range particle size spectra collected on a major highway, Environ. Sci. Technol., 45, 5522-5528, 2011.

Harrison, R. M., Dall'Osto, M., Beddows, D. C. S., Thorpe, A. J., Bloss, W. J., Allan, J. D., Coe, H., Dorsey, J. R., Gallagher, M., Martin, C., Whitehead, J., Williams, P. I., Jones, R. L., Langridge, J. M., Benton, A. K., Ball, S. M., Langford, B., Hewitt, C. N., Davison, B., Martin, D., Petersson, K. F., Henshaw, S. J., White, I. R., Shallcross, D. E., Barlow, J. F., Dunbar, T., Davies, F., Nemitz, E., Phillips, G. J., Helfter, C., Di Marco, C. F., and Smith, S.: Atmospheric chemistry and physics in the atmosphere of a developed megacity (London): an overview of the REPARTEE experiment and its conclusions, Atmos. Chem. Phys., 12, 3065-3114, https://doi.org/10.5194/acp-12-3065-2012, 2012.

Harrison, R. M., Beddows, D. C., Jones, A. M., Calvo, A., Alves, C., and Pio, C.: An evaluation of some issues regarding the use of aethalometers to measure woodsmoke concentrations, Atmos. Environ., 80, 540-548, 2013.

Harrison, R. M., Jones, A. M., Beddows, D. C. S., Dall'Osto, M., and Nikolova, I.: Evaporation of traffic-generated nanoparticles during advection from source, Atmos. Environ., 125, 1-7, 2016.

Herndon, S. C., Jayne, J. T., Lobo, P., Onasch, T. B., Fleming, G., Hagen, D. E., Whitefield, P. D., and Miake-Lye, R. C.: Commercial aircraft engine emissions characterization of in-use aircraft at Hartsfield-Jackson Atlanta International Airport, Environ. Sci. Technol., 42, 1877-1883, 2008.

Hopke, P. K.: Review of receptor modeling methods for source apportionment, J. Air Waste Manage., 66, 237-259, 2016.
Hsu, H. H., Adamkiewicz, G., Houseman, E. A., Vallarino, J., Melly, S. J., Wayson, R. L., Spengler, J. D., and Levy, J. I.: The relationship between aviation activities and ultrafine particulate matter concentrations near a mid-sized airport, Atmos. Environ., 50, 328-337, 2012a.

Hsu, H. H., Adamkiewicz, G., Houseman, E. A., Vallarino, J., Melly, S. J., Wayson, R. L., Spengler, J. D., and Levy, J. I.: The relationship between aviation activities and ultrafine particulate matter concentrations near a mid-sized airport, Atmos. Environ., 50, 328-337, 2012b.

Hsu, H. H., Adamkiewicz, G., Houseman, E. A., Zarubiak, D., Spengler, J. D., and Levy, J. I.: Contributions of aircraft arrivals and departures to ultrafine particle counts near Los Angeles International Airport, Sci. Total Environ., 444, 347-355, 2013.

Hsu, H. H., Adamkiewicz, G., Houseman, E. A., Spengler, J. D., and Levy, J. I.: Using mobile monitoring to characterize roadway and aircraft contributions to ultrafine particle concentrations near a mid-sized airport, Atmos. Environ., 89, 688-695, 2014.

Hu, S., Fruin, S., Kozawa, K., Mara, S., Winer, A. M., and Paulson, S. E.: Aircraft emission impacts in a neighborhood adjacent to a general aviation airport in Southern California, Environ. Sci. Technol., 43, 8039-8045, 2009.

Hudda, N. and Fruin, S. A.: International airport impacts to air quality: size and related properties of large increases in ultrafine particle number concentrations, Environ. Sci. Technol., 50, 3362 3370, 2016.

Hudda, N., Gould, T., Hartin, K., Larson, T. V., and Fruin, S. A.: Emissions from an international airport increase particle number concentrations 4-fold at $10 \mathrm{~km}$ downwind, Environ. Sci. Technol., 48, 6628-6635, 2014.

Hudda, N., Simon, M. C., Zamore, W., Brugge, D., and Durant, J. L.: Aviation emissions impact ambient ultrafine particle concentrations in the greater Boston area, Environ. Sci. Technol., 50, 8514-8521, 2016.

Hussein, T., Molgaard, B., Hannuniemi, H., Martikainen, J., Jarvi, L., Wegner, T., Ripamonti, G., Weber, S., Vesala, T., and Hameri, K.: Fingerprints of the urban particle number size distribution in Helsinki, Finland: local vs. regional characteristics, Boreal Environ. Res., 19, 1-20, 2014.

ICAO (International Civil Aviation Organization): Annual Report of the ICAO Council: 2014. The World of Air Transport in 2014, Appendix 1, available at: https://www.icao. int/annual-report-2014/Documents/Appendix_1_en.pdf, last access: 20 June 2017, 2014.

Janhäll, S., Jonsson, Å. M., Molnár, P., Svensson, E. A., and Hallquist, M.: Size resolved traffic emission factors of submicrometer particles, Atmos. Environ., 38, 4331-4340, 2004.

Jones, A. M., Harrison, R. M., Barratt, B., and Fuller, G.: A large reduction in airborne particle number concentrations at the time of the introduction of "sulphur free" diesel and the London Low Emission Zone, Atmos. Environ., 50, 129-138, 2012.

Kasumba, J., Hopke, P. K., Chalupa, D. C., and Utell, M. J.: Comparison of sources of submicron particle number concentrations measured at two sites in Rochester, NY, Sci. Total Environ., 407, 5071-5084, 2009.

Kelly, F. J. and Fussell, J. C.: Size, source and chemical composition as determinants of toxicity attributable to ambient particulate matter, Atmos. Environ., 60, 504-526, 2012. 
Kerminen, V. M., Pirjola, L., Boy, M., Eskola, A., Teinilä, K., Laakso, L., Asmi, A., Hienola, J., Lauri, A., Vainio, V., and Lehtinen, K.: Interaction between $\mathrm{SO} 2$ and submicron atmospheric particles, Atmos. Res., 54, 41-57, 2000.

Keuken, M. P., Moerman, M., Zandveld, P., Henzing, J. S., and Hoek, G.: Total and size-resolved particle number and black carbon concentrations in urban areas near Schiphol airport (the Netherlands), Atmos. Environ., 104, 132-142, 2015.

Kim, E., Hopke, P. K., Larson, T. V., and Covert, D. S.: Analysis of ambient particle size distributions using unmix and positive matrix factorization, Environ. Sci. Technol., 38, 202-209, 2004.

Kinsey, J. S., Dong, Y., Williams, D. C., and Logan, R.: Physical characterization of the fine particle emissions from commercial aircraft engines during the aircraft particle emissions experiment (APEX) 1 to 3, Atmos. Environ., 44, 2147-2156, 2010.

Klapmeyer, M. E. and Marr, L. C.: $\mathrm{CO}_{2}, \mathrm{NO}_{x}$, and particle emissions from aircraft and support activities at a regional airport, Environ. Sci. Technol., 46, 10974-10981, 2012.

Kley, D., Kleinmann, M., Sanderman, H., and Krupa, S.: Photochemical oxidants: state of the science, Environ. Pollut., 100, 1942, 1999.

Knibbs, L. D., Cole-Hunter, T., and Morawska, L.: A review of commuter exposure to ultrafine particles and its health effects, Atmos. Environ., 45, 2611-2622, 2011.

Kruskal, W. H. and Wallis, W. A., Use of ranks in one-criterion variance analysis, J. Am. Stat. Assoc., 47, 583-621, 1952.

Kulmala, M. and Kerminen, V.-M.: On the formation and growth of atmospheric nanoparticles, Atmos. Res., 90, 132-150, 2008.

Kulmala, M., Toivonen, A., Mäkelä, J. M., and Laaksonen, A.: Analysis of the growth of nucleation mode particles observed in Boreal forest, Tellus B, 50, 449-462, 1998.

Kumar, P., Pirjola, L., Ketzel, M., and Harrison, R. M.: Nanoparticle emissions from 11 non-vehicle exhaust sources - a review, Atmos. Environ., 67, 252-277, 2013.

Kumar, P., Morawska, L., Birmili, W., Paasonen, P., Hu, M., Kulmala, M., Harrison, R. M., Norford, L., and Britter, R.: Ultrafine particles in cities, Environ. Int., 66, 1-10, 2014.

Lanzinger, S., Schneider, A., Breitner, S., Stafoggia, M., Erzen, I., Dostal, M., Pastorkova, A., Bastian, S., Cyrys, J., Zscheppang, A., and Kolodnitska, T.: Associations between ultrafine and fine particles and mortality in five central European cities Results from the UFIREG study, Environ. Int., 88, 44-52, 2016.

Lee, D. S., Fahey, D. W., Forster, P. M., Newton, P. J., Wit, R. C. N., Lim, L. L., Owen, B., and Sausen, R.: Aviation and global climate change in the 21st century, Atmos. Environ., 43, 35203537, 2009.

Liu, Z. R., Hu, B., Liu, Q., Sun, Y., and Wang, Y. S.: Source apportionment of urban fine particle number concentration during summertime in Beijing, Atmos. Environ., 96, 359-369, 2014.

Lobo, P., Hagen, D. E., and Whitefield, P. D.: Measurement and analysis of aircraft engine PM emissions downwind of an active runway at the Oakland International Airport, Atmos. Environ., 61, 114-123, 2012.

Lobo, P., Hagen, D. E., Whitefield, P. D., and Raper, D.: PM emissions measurements of in-service commercial aircraft engines during the Delta-Atlanta Hartsfield Study, Atmos. Environ., 104, 237-245, 2015

Lupu, A. and Maenhaut, W.: Application and comparison of two statistical trajectory techniques for identification of source re- gions of atmospheric aerosol species, Atmos. Environ., 36, 5607-5618, 2002.

Masiol, M. and Harrison, R. M.: Aircraft engine exhaust emissions and other airport-related contributions to ambient air pollution: a review, Atmos. Environ., 95, 409-455, 2014.

Masiol, M. and Harrison, R. M.: Quantification of air quality impacts of London Heathrow Airport (UK) from 2005 to 2012, Atmos. Environ., 116, 308-319, 2015.

Masiol, M., Vu, V. T., Beddows, D. C. S., and Harrison, R. M.: Source apportionment of wide range particle size spectra and black carbon collected at the airport of Venice (Italy), Atmos. Environ., 139, 56-74, 2016.

Masiol, M., Hopke, P. K., Felton, H. D., Frank, B. P., Rattigan, O. V., Wurth, M. J., and LaDuke, G. H.: Source apportionment of $\mathrm{PM}_{2.5}$ chemically speciated mass and particle number concentrations in New York City, Atmos. Environ., 148, 215-229, 2017.

Mazaheri, M., Johnson, G. R., and Morawska, L.: Particle and gaseous emissions from commercial aircraft at each stage of the landing and takeoff cycle, Environ. Sci. Technol., 43, 441-446, 2009.

Mazaheri, M., Bostrom, T. E., Johnson, G. R., and Morawska, L.: Composition and morphology of particle emissions from in-use aircraft during takeoff and landing, Environ. Sci. Technol., 47, 5235-5242, 2013.

Meyer, N. K. and Ristovski, Z.: Ternary nucleation as a mechanism for the production of diesel nanoparticles: experimental analysis of the volatile and hygroscopic properties of diesel exhaust using the volatilization and humidification tandem differential mobility analyser, Environ. Sci. Technol., 41, 7309-7314, 2007.

Ntziachristos, L., Ning, Z., Geller, M. D., and Sioutas, C.: Particle concentration and characteristics near a major freeway with heavy-duty diesel traffic, Environ. Sci. Technol., 41, 2223-2230, 2007.

O’Dowd, C. D., Geever, M., Hill, M. K., Smith, M. H., and Jennings, S. G.: New particle formation: nucleation rates and spatial scales in the clean marine coastal environment, Geophys. Res. Lett., 25, 1661-1664, 1998.

O’Dowd, C., McFiggans, G., Creasey, D. J., Pirjola, L., Hoell, C., Smith, M. H., Allan, B. J., Plane, J. M. C., Heard, D. E., Lee, J. D., Pilling, M. J., and Kulmala, M.: On the photochemical production of new particles in the coastal boundary layer, Geophys. Res. Lett., 26, 1707-1710, 1999.

Ogulei, D., Hopke, P. K., Chalupa, D. C., and Utell, M. J.: Modeling source contributions to submicron particle number concentrations measured in Rochester, New York, Aerosol Sci. Tech., 41, 179-201, 2007.

Ostro, B., Hu, J., Goldberg, D., Reynolds, P., Hertz, A., Bernstein, L., and Kleeman, M. J.: Associations of mortality with long-term exposures to fine and ultrafine particles, species and sources: results from the California Teachers Study Cohort, Environ. Health Persp., 123, 549-556, 2015.

Paatero, P.: Least squares formulation of robust non-negative factor analysis, Chemometr. Intell. Lab., 37, 23-35, 1997.

Paatero, P. and Tapper, U.: Positive matrix factorization: a nonnegative factor model with optimal utilization of error estimates of data values, Environmetrics, 5, 111-126, 1994.

Paatero, P., Hopke, P. K., Song, X. H., and Ramadan, Z.: Understanding and controlling rotations in factor analytic models, Chemometr. Intell. Lab., 60, 253-264, 2002. 
Paatero, P., Eberly, S., Brown, S. G., and Norris, G. A.: Methods for estimating uncertainty in factor analytic solutions, Atmos. Meas. Tech., 7, 781-797, https://doi.org/10.5194/amt-7781-2014, 2014.

Pant, P. and Harrison, R. M.: Estimation of the contribution of road traffic emissions to particulate matter concentrations from field measurements: a review, Atmos. Environ., 77, 78-97, 2013.

Petzold, A., Ogren, J. A., Fiebig, M., Laj, P., Li, S.-M., Baltensperger, U., Holzer-Popp, T., Kinne, S., Pappalardo, G., Sugimoto, N., Wehrli, C., Wiedensohler, A., and Zhang, X.-Y.: Recommendations for reporting "black carbon" measurements, Atmos. Chem. Phys., 13, 8365-8379, https://doi.org/10.5194/acp13-8365-2013, 2013.

R Core Team: R: a language and environment for statistical computing. R Foundation for Statistical Computing, Vienna, Austria, available at: http://www.R-project.org/ (last access: 2 October 2017), 2015.

Reff, A., Eberly, S. I., and Bhave, P. V.: Receptor modeling of ambient particulate matter data using positive matrix factorization: review of existing methods, J. Air Waste Manage., 57, 146-154, 2007.

Ren, J., Liu, J., Li, F., Cao, X., Ren, S., Xu, B., and Zhu, Y.: A study of ambient fine particles at Tianjin International Airport, China, Sci. Total Environ., 556, 126-135, 2016.

Riccobono, F., Schobesberger, S., Scott, C. E., Dommen, J., Ortega, I. K., Rondo, L., Almeida, J., Amorim, A., Bianchi, F., Breitenlechner, M., and David, A.: Oxidation products of biogenic emissions contribute to nucleation of atmospheric particles, Science, 344, 717-721, 2014.

Rolph, G. D.: Real-Time Environmental Applications and Display sYstem (READY) Website, available at: http://www.ready.noaa. gov, NOAA Air Resources Laboratory, College Park, MD, 2016.

Salimi, F., Ristovski, Z., Mazaheri, M., Laiman, R., Crilley, L. R., He, C., Clifford, S., and Morawska, L.: Assessment and application of clustering techniques to atmospheric particle number size distribution for the purpose of source apportionment, Atmos. Chem. Phys., 14, 11883-11892, https://doi.org/10.5194/acp-1411883-2014, 2014.

Salma, I., Füri, P., Németh, Z., Balásházy, I., Hofmann, W., and Farkas, Á.: Lung burden and deposition distribution of inhaled atmospheric urban ultrafine particles as the first step in their health risk assessment, Atmos. Environ., 104, 39-49, 2015.

Sandradewi, J., Prévôt, A. S., Szidat, S., Perron, N., Alfarra, M. R., Lanz, V. A., Weingartner, E., and Baltensperger, U.: Using aerosol light absorption measurements for the quantitative determination of wood burning and traffic emission contributions to particulate matter, Environ. Sci. Technol., 42, 3316-3323, 2008.

Schneider, J., Hock, N., Weimer, S., Borrmann, S., Kirchner, U., Vogt, R., and Scheer, V.: Nucleation particles in diesel exhaust: composition inferred from in situ mass spectrometric analysis, Environ. Sci. Technol., 39, 6153-6161, 2005.

Seinfeld, J. H. and Pandis, S. N.: Atmospheric Chemistry Physics - From Air Pollution to Climate Change, 2nd Edn., John Wiley and Sons, New York, 2006.

Shi, J. P. and Harrison, R. M.: Investigation of ultrafine particle formation during diesel exhaust dilution, Environ. Sci. Technol., 33, 3730-3736, 1999.

Shirmohammadi, F., Sowlat, M. H., Hasheminassab, S., Saffari, A., Ban-Weiss, G., and Sioutas, C.: Emission rates of particle num- ber, mass and black carbon by the Los Angeles International Airport (LAX) and its impact on air quality in Los Angeles, Atmos. Environ., 151, 82-93, 2017.

Sowlat, M. H., Hasheminassab, S., and Sioutas, C.: Source apportionment of ambient particle number concentrations in central Los Angeles using positive matrix factorization (PMF), Atmos. Chem. Phys., 16, 4849-4866, https://doi.org/10.5194/acp16-4849-2016, 2016.

Squizzato, S. and Masiol, M.: Application of meteorology-based methods to determine local and external contributions to particulate matter pollution: a case study in Venice (Italy), Atmos. Environ., 119, 69-81, 2015.

Stafoggia, M., Cattani, G., Forastiere, F., di Bucchianico, A. D. M., Gaeta, A., and Ancona, C.: Particle number concentrations near the Rome-Ciampino city airport, Atmos. Environ., 147, 264-273, 2016.

Stein, A. F., Draxler, R. R., Rolph, G. D., Stunder, B. J. B., Cohen, M. D., and Ngan, F.: NOAA's HYSPLIT atmospheric transport and dispersion modeling system, B. Am. Meteorol. Soc., 96, 2059-2077, 2015.

Stevens, R. G., Pierce, J. R., Brock, C. A., Reed, M. K., Crawford, J. H., Holloway, J. S., Ryerson, T. B., Huey, L. G., and Nowak, J. B.: Nucleation and growth of sulfate aerosol in coal-fired power plant plumes: sensitivity to background aerosol and meteorology, Atmos. Chem. Phys., 12, 189-206, https://doi.org/10.5194/acp12-189-2012, 2012.

Stohl, A.: Trajectory statistics - a new method to establish sourcereceptor relationships of air pollutants and its application to the transport of particulate sulfate in Europe, Atmos. Environ., 30, 579-587, 1996.

Stohl, A.: Computation, accuracy and applications of trajectories review and bibliography, Atmos. Environ., 32, 947-966, 1998.

Strak, M. M., Janssen, N. A., Godri, K. J., Gosens, I., Mudway, I. S., Cassee, F. R., Lebret, E., Kelly, F. J., Harrison, R. M., Brunekreef, B., and Steenhof, M.: Respiratory health effects of airborne particulate matter: the role of particle size, composition, and oxidative potential - the RAPTES project, Environ. Health Persp., 120, 1183-1189, 2012.

Thimmaiah, D., Hovorka, J., and Hopke, P. K.: Source apportionment of winter submicron Prague aerosols from combined particle number size distribution and gaseous composition data, Aerosol Air Qual. Res., 9, 209-236, 2009.

Turner, J. R., Hansen, A. D. A., and Allen, G. A.: Methodologies to compensate for optical saturation and scattering in aethalometer black carbon measurements, in: Proceedings from the Symposium on Air Quality Measurement Methods and Technology, San Francisco, CA, USA, 30 April-3 May 2007, Air and Waste Management Association, 2007.

UK Department for Transport: Heathrow Airport expansion: https://www.gov.uk/government/collections/ heathrow-airport-expansion, last access: 20 June 2017.

U.S. EPA: EPA Positive Matrix Factorization (PMF) 5.0 - Fundamentals and user guide, EPA/600/R-14/108, Washington, DC, United States, 2014.

Virkkula, A., Mäkelä, T., Hillamo, R., Yli-Tuomi, T., Hirsikko, A., Hämeri, K., and Koponen, I. K.: A simple procedure for correcting loading effects of aethalometer data, J. Air Waste Manage., 57, 1214-1222, 2007. 
Vogt, R., Scheer, V., Casati, R., and Benter, T.: Onroad measurement of particle emission in the exhaust plume of a diesel passenger car, Environ. Sci. Technol., 37, 4070-4076, 2003.

von Bismarck-Osten, C., Birmili, W., Ketzel, M., Massling, A., Petäjä, T., and Weber, S.: Characterization of parameters influencing the spatio-temporal variability of urban particle number size distributions in four European cities, Atmos. Environ., 77, 415-429, 2013.

Vu, T. V., Delgado-Saborit, J. M., and Harrison, R. M.: A review of hygroscopic growth factors of submicron aerosols from different sources and its implication for calculation of lung deposition efficiency of ambient aerosols, Air Qual. Atmos. Hlth., 8, 429-440, 2015a.

Vu, T. V., Delgado-Saborit, J. M., and Harrison, R. M.: Review: Particle number size distributions from seven major sources and implications for source apportionment studies, Atmos. Environ., 122, 114-132, 2015b.

Vu, T. V., Beddows, D. C. S., Delgado-Saborit, J. M., and Harrison, R. M.: Source apportionment of the lung dose of ambient submicrometre particulate matter, Aerosol Air Qual. Res., 16, 1548-1557, https://doi.org/10.4209/aaqr.2015.09.0553, 2016.

Yin, J., Harrison, R. M., Chen, Q., Rutter, A., and Schauer, J. J.: Source apportionment of fine particles at urban background and rural sites in the UK atmosphere, Atmos. Environ., 44, 841-851, 2010.

Yue, W., Stolzel, M., Cyrys, J., Pitz, M., Heinrich, J., Kreyling, W. G., Wichmann, H.-E.,Peters, A., Wang, S., and Hopke, P. K.: Source apportionment of ambient fine particle size distribution using positive matrix factorization in Erfurt, Germany, Sci. Total Environ., 398, 133-144, 2008.

Wang, Y., Hopke, P. K., Rattigan, O. V., Xia, X., Chalupa, D. C., and Utell, M. J.: Characterization of residential wood combustion particles using the two-wavelength aethalometer, Environ. Sci. Technol., 45, 7387-7393, 2011.

Webb, S., Whitefield, P. D., Miake-Lye, R. C., Timko, M. T., and Thrasher, T. G.: Research needs associated with particulate emissions at airports, ACRP Report 6, Transportation Research Board, Washington, D. C., 2008.
Wegner, T., Hussein, T., Hämeri, K., Vesala, T., Kulmala, M., and Weber, S.: Properties of aerosol signature size distributions in the urban environment as derived by cluster analysis, Atmos. Environ., 61, 350-360, 2012.

Wehner, B., Uhrner, U., Von Löwis, S., Zallinger, M., and Wiedensohler, A.: Aerosol number size distributions within the exhaust plume of a diesel and a gasoline passenger car under on-road conditions and determination of emission factors, Atmos. Environ., 43, 1235-1245, 2009.

Westerdahl, D., Fruin, S. A., Fine, P. L., and Sioutas, C.: The Los Angeles International Airport as a source of ultrafine particles and other pollutants to nearby communities, Atmos. Environ., 42, 3143-3155, 2008

Zhang, K. M., Wexler, A. S., Zhu, Y. F., Hinds, W. C., and Sioutas, C.: Evolution of particle number distribution near roadways. Part II: The "Road-to-Ambient"process, Atmos. Environ., 38, 6655-6665, 2004.

Zhang, K. M., Wexler, A. S., Niemeier, D. A., Zhu, Y. F., Hinds, W. C., and Sioutas, C.: Evolution of particle number distribution near roadways. Part III: Traffic analysis and on-road size resolved particulate emission factors, Atmos. Environ., 39, 4155-4166, 2005.

Zhang, R., Khalizov, A., Wang, L., Hu, M., and Xu, W.: Nucleation and growth of nanoparticles in the atmosphere, Chem. Rev., 112, 1957-2011, 2011.

Zhou, L., Hopke, P. K., Stanier, C. O., Pandis, S. N., Ondov, J. M., and Pancras, J. P.: Investigation of the relationship between chemical composition and size distribution of airborne particles by partial least squares and positive matrix factorization, J. Geophys. Res.-Atmos., 110, D07S18, https://doi.org/10.1029/2004JD005050, 2005.

Zíková, N., Wang, Y., Yang, F., Li, X., Tian, M., and Hopke, P. K.: On the source contribution to Beijing $\mathrm{PM}_{2.5}$ concentrations, Atmos. Environ., 134, 84-95, 2016. 